\title{
Chile: 2004 Article IV Consultation-Staff Report; Public Information Notice on the Executive Board Discussion; and Statement by the Executive Director for Chile
}

Under Article IV of the IMF's Articles of Agreement, the IMF holds bilateral discussions with members, usually every year. In the context of the 2004 Article IV consultation with Chile, the following documents have been released and are included in this package:

- $\quad$ the staff report for the 2004 Article IV consultation, prepared by a staff team of the IMF, following discussions that ended on May 28, 2004, with the officials of Chile on economic developments and policies. Based on information available at the time of these discussions, the staff report was completed on July 12, 2004. The views expressed in the staff report are those of the staff team and do not necessarily reflect the views of the Executive Board of the IMF.

- $\quad$ a Public Information Notice (PIN) summarizing the views of the Executive Board as expressed during its August 4, 2004 discussion of the staff report that concluded the Article IV consultation.

- $\quad$ a statement by the Executive Director for Chile.

The document listed below have been or will be separately released.

\section{Selected Issues Paper}

The policy of publication of staff reports and other documents allows for the deletion of market-sensitive information.

To assist the IMF in evaluating the publication policy, reader comments are invited and may be sent by e-mail to publicationpolicy@imf.org.

$$
\begin{gathered}
\text { Copies of this report are available to the public from } \\
\text { International Monetary Fund • Publication Services } \\
70019^{\text {th }} \text { Street, N.W. • Washington, D.C. } 20431 \\
\text { Telephone: (202) 623-7430 • Telefax: (202) 623-7201 } \\
\text { E-mail: publications@imf.org • Internet: http://www.imf.org }
\end{gathered}
$$

Price: $\$ 15.00$ a copy

\section{International Monetary Fund \\ Washington, D.C.}



INTERNATIONAL MONETARY FUND

\section{CHILE}

\section{Staff Report for the 2004 Article IV Consultation}

Prepared by the Staff Representatives for the 2004 Consultation with Chile

Approved by José Fajgenbaum and Juha Kähkönen

July 12,2004

- Discussions. A staff team held discussions in Santiago during May 17-28. The team met with the Minister of Finance; the Minister of Economy and Energy; the Minister of Planning and Cooperation; the President of the Central Bank; other senior officials; and representatives of the private sector and the academic community.

- Team. The staff team comprised G. Terrier (Head), M. Espinosa, C. Faulkner-MacDonagh, R. Luzio (all WHD), and J. Chan-Lau (ICM). A. Ize (MFD) joined the mission on May 19-20 to discuss the results of the FSAP findings and recommendations, and F. Nadal de Simone (EUR) on May 24 to discuss inflation targeting issues. M. Vera Martin (ICM) contributed to the work on international reserves. A. Singh (WHD) took part in the concluding discussions. Mr. Le Fort, the Executive Director for Chile, attended the key meetings.

- Previous consultation. At the conclusion of the 2003 Article IV consultation, on August 18, 2003, Directors commended the Chilean authorities for implementing a sound policy framework, based on inflation targeting, exchange rate flexibility, and a prudent target for the structural fiscal balance. They considered that these policies, in conjunction with other strong fundamentals, such as transparent institutions, an open trade regime, and sound banking and financial regulatory systems, have allowed Chile continued stability and economic growth. Directors emphasized the importance of enhancing progress in addressing constraints to growth and employment through regulatory, capital market, and social sector reform, including those in the Pro-Growth Agenda reform. Directors also urged the authorities to enhance labor market flexibility, including by moving ahead on their commitment to make work schedules more flexible (the staff report was published as IMF Country Report No. 03/303).

- Relations with the Fund. Chile has accepted the obligations of Article VIII, sections 2, 3, and 4 and maintains an exchange system that is free of restrictions on the making of payments and transfers for current international transactions. Chile participates in the New Arrangements to Borrow and subscribes to the Fund's Special Data Dissemination Standard. A fiscal ROSC was published in August 2003, and an FSSA report accompanies this staff report.

- Selected Issues Papers. Background papers for the Article IV consultation include: (i) an analysis of Chile's holdings of international reserves; (ii) an assessment of the use of forward hedging in the economy; (iii) an analysis of indexed peso-denominated bond issues; and (iv) recent trends in potential output. 


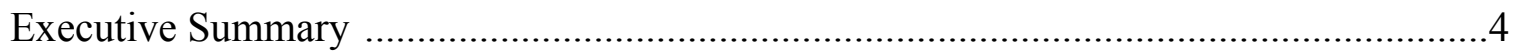

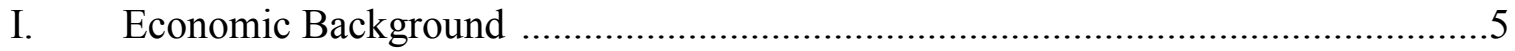

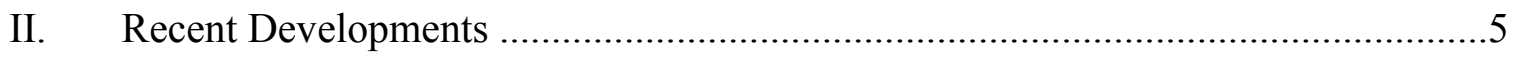

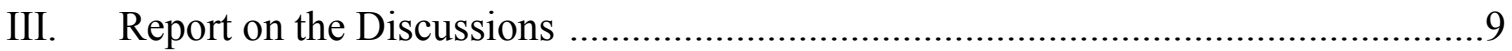

A. Short-Term Economic Prospects and Risks ............................................. 10

B. Fiscal Policy and Structural Balance Rule ...................................................12

C. Maintaining a Strong and Credible Monetary Policy Framework ..................15

D. Enhancing the Strength of the Financial Sector ............................................ 18

E. Sustaining Strong Economic Growth into the Medium-Term ......................20

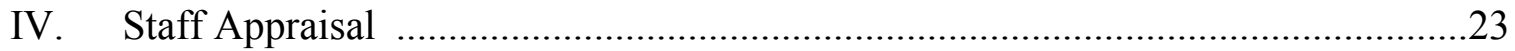

\section{Text Boxes}

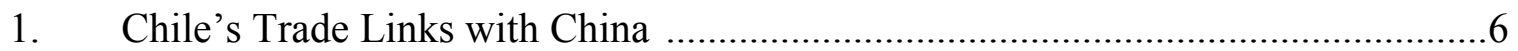

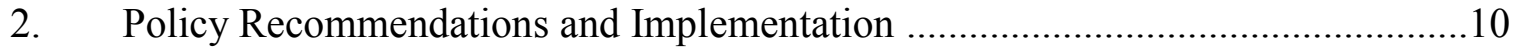

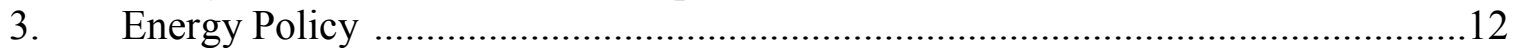

4. Fiscal Balance: Comparison with OECD Countries ..........................................13

5. Central Bank Communication Strategy .........................................................16

6. Financial System Stability Assessment (FSSA): Summary of Findings ...............19

Tables

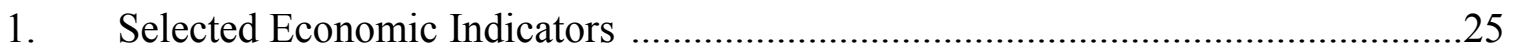

2. Summary Operations of the Central Government ............................................26

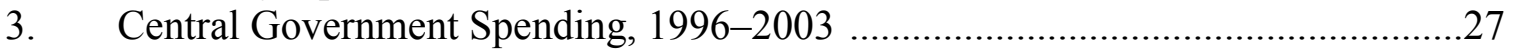

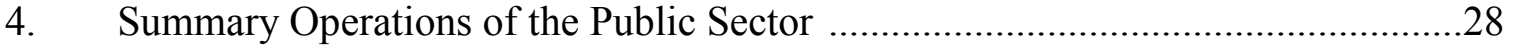

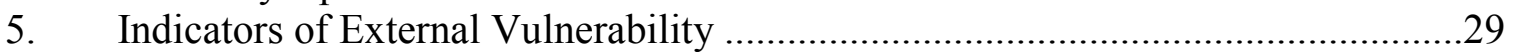

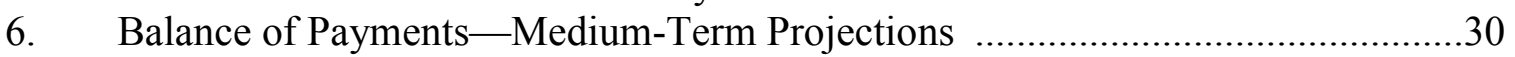

7. External Debt and Debt Service Projections ........................................................ 31

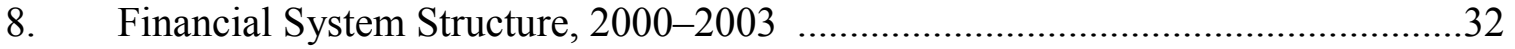

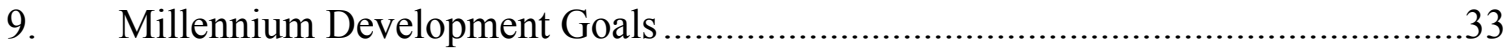

Figures

1. Economic Activity and Copper Prices ..................................................................

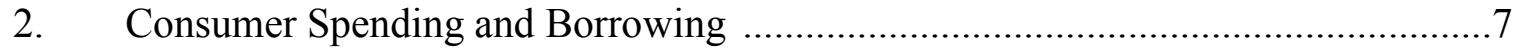

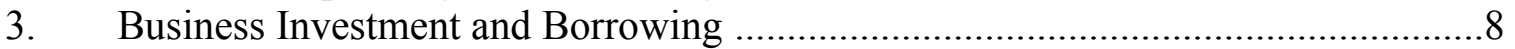

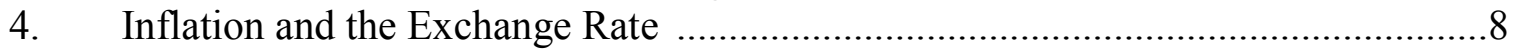

5. Inflation and the BCCh Target Band .................................................................

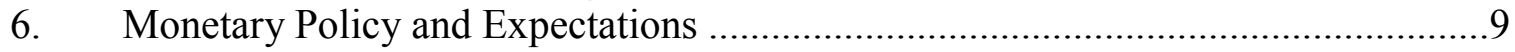

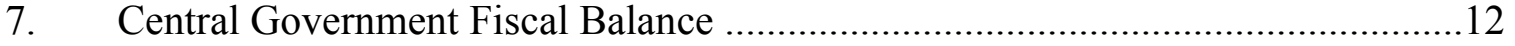




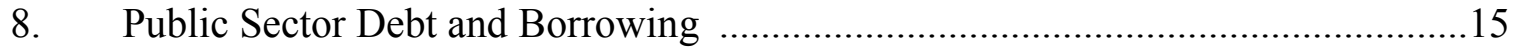

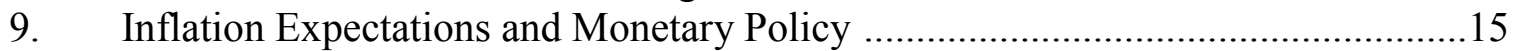

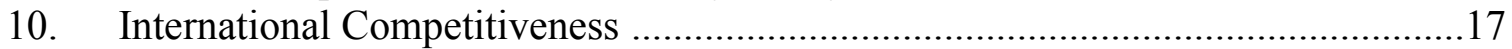

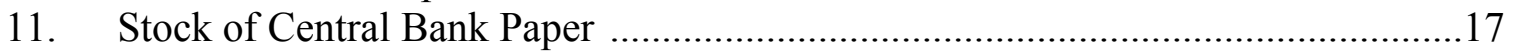

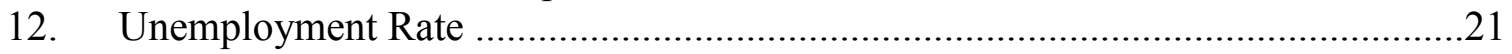

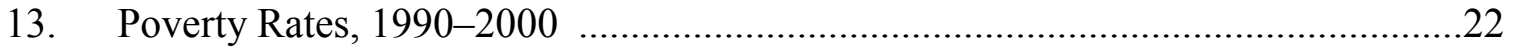

\section{Appendices}

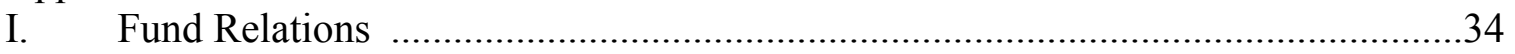

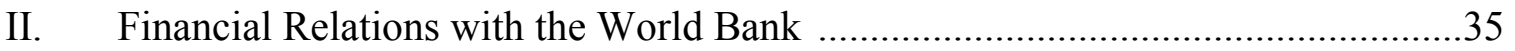

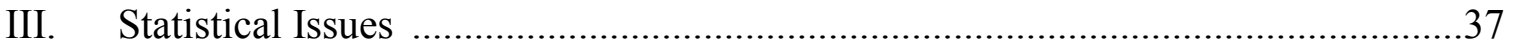

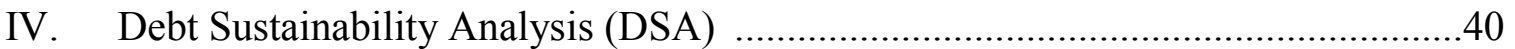

V. Pro-Growth Agenda: Description and Update ............................................44 


\section{EXECUTIVE SUMMARY}

\section{Economic outlook}

- $\quad$ Economic activity is picking up and real GDP is projected to grow by about 5 percent a year in 2004 and 2005. Private investment is gradually increasing, but unemployment remains relatively high, at about 9 percent in May. Reflecting the recovery in world demand, copper prices remain high, and the external current account is projected to register a surplus of 1 percent of GDP in 2004.

- Inflation fell below the target band in early 2004, but it is expected to return within the 2-4 percent band by year-end. The sharp appreciation of the peso during the second half of 2003 helps explain the decline in inflation in the early part of this year. However, inflation expectations are well anchored, and 12-month inflation is projected at about 2 percent by end-2004.

- $\quad$ The risks of disruption of natural gas imports from Argentina appear manageable. The authorities are taking steps to promote a gradual shift from gas to other sources of electricity generation.

\section{Policy discussions}

- $\quad$ The government is firmly committed to the structural fiscal balance rule. Full adherence to the rule is a challenge this year, given calls to increase spending in the context of high copper prices. So far, the government has successfully resisted such pressure and has also prudently used most of the surpluses accumulated by the Copper Stabilization Fund in recent months to repay expensive debt.

- Staff shared the authorities' view that monetary policy can continue to support domestic demand for some time, particularly given the output gap. The authorities reaffirmed their commitment to tighten policies when their estimates show that, on a sustained basis, inflation would move above the mid-range of the target band.

- $\quad$ As highlighted in the companion Financial System Stability Assessment (FSSA) report, the Chilean financial system is strong, with room for greater competition. The authorities have indicated that they plan to follow up on FSAP recommendations.

- With Presidential and congressional elections in late 2005, attention is turning to the agenda to sustain high economic growth. This is leading to a rich public debate on education reform, labor productivity, and income distribution. 


\section{ECONOMIC BACKGROUND}

1. Over the past two decades, Chile has adhered to a sound and consistent policy framework. The focus has been on prudent macroeconomic policies and open trade and, in recent years, inflation targeting and achievement of a structural surplus in the accounts of the central government. In the area of monetary policy, the authorities have been successfully implementing inflation targeting, and 12-month inflation has been reduced from about 8 percent in the mid-1990s to 1 percent during 2003. The authorities have allowed the exchange rate to fluctuate freely since end-2001. In the fiscal area, the authorities have strictly contained central government spending and adhered closely to the fiscal rule, introduced by the current administration in 2000 .

\section{These policies have been successful at fostering growth and macroeconomic} stability. Over 1980-2003, Chile was able to narrow the relative income gap with advanced economies (per capita income rose from about 20 percent of the U.S. per capita income in the early 1980s to close to 30 percent in 2002). During this period, Chile was the fastest growing country in Latin America, with average annual per capita income growth of $3 \frac{1}{4}$ percent. Although this performance fell significantly short of that in Asia (51/4 percent), it was well above the average for Latin America ( $1 / 2$ percent). Chile's GDP per capita growth slowed to $1 \frac{1}{4}$ percent during 1998-2003, but this still compared favorably with Latin America as a whole, which registered a slight decline.

3. Chile's future challenge is to return to a path of strong growth while ensuring that its benefits are shared more equitably. Despite a sharp reduction in poverty, the recent slowdown in growth has further impeded progress in addressing income inequality. According to a recent World Bank report on Latin America, Chile's income inequality is high—second only to Brazil.

\section{RECENT DEVELOPMENTS}

4. Economic activity has picked up since the beginning of 2004, in the context of a very favorable external environment. The recovery in the global economy, including the strength of economic activity in China, has helped boost export prices and demand, particularly for copper-Chile's main export commodity, the price of which has surged (Figure 1 and Box 1). ${ }^{1}$
Figure 1. Economic activity and copper prices

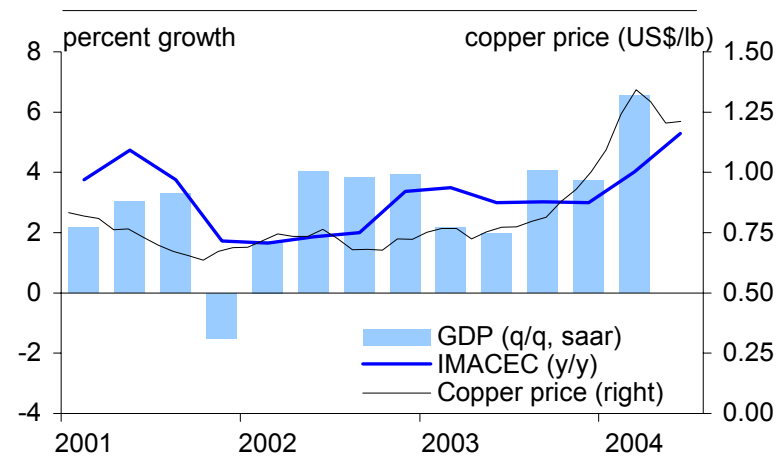

\footnotetext{
${ }^{1}$ Copper accounts for 10 percent of Chile's GDP and about 40 percent of its exports of goods. The price of copper surged from US\$0.72 a pound in December 2002 to US\$1.30-1.40 a pound in March-April 2004 (in early July, copper prices stood at about US\$1.25 a pound).
} 
Chile has also benefited from low world interest rates, and - following ratings upgradessovereign spreads have hovered at about 90 basis points, well below the regional average of just over 600 basis points. Reflecting, in part, these developments, real GDP grew by $61 / 2$ percent (q/q, seasonally adjusted) during the first quarter, the strongest quarterly growth in three years.

\section{Box 1. Chile's Trade Links With China}

Chile's trade with China has experienced remarkable growth in recent years. During 1998-2003, Chile's exports to, and imports from, China grew by 41 percent and 13 percent a year, respectively. In 2003, China absorbed 9 percent of Chile's exports - copper represented 70 percent of the total, reflecting China's strong demand for base metals.

China is the world's largest consumer of copper. China's copper demand is equivalent to 20 percent of total world demand, with Chile supplying about half of its external copper needs. China's copper demand has grown by over 15 percent a year since 1998, and it accounted for 120 percent of the global demand increase in 2003. The strong growth in fixed investment (28 percent in 2003) has been the main cause for China's demand for base metals. With almost half of copper demand going to electricity generation equipment, China's efforts to boost electricity supply would suggest that its copper imports will remain strong in the coming years, and it is expected to remain a major importer of copper in the period ahead. ${ }^{1}$ World inventories are at low levels, and copper prices are expected to remain above current production costs for some time.

Chile is well positioned to benefit from growing trade links with China. In 2003, Chile had a trade surplus with China of over 1 percent of GDP. The two countries' comparative trade advantages are complementary, as reflected in the current composition of trade flows. Chinese exports are concentrated mostly in consumer goods, which accounted for 25 percent of Chile's imports of consumer goods. Chilean exports are focused on raw commodities and commodity-based industrial goods. The authorities are conducting a feasibility study for a wide-ranging trade agreement, expected to be completed by the fall of 2004 .

\section{Figure: World Copper Market}

World copper consumption and production, as share of the total

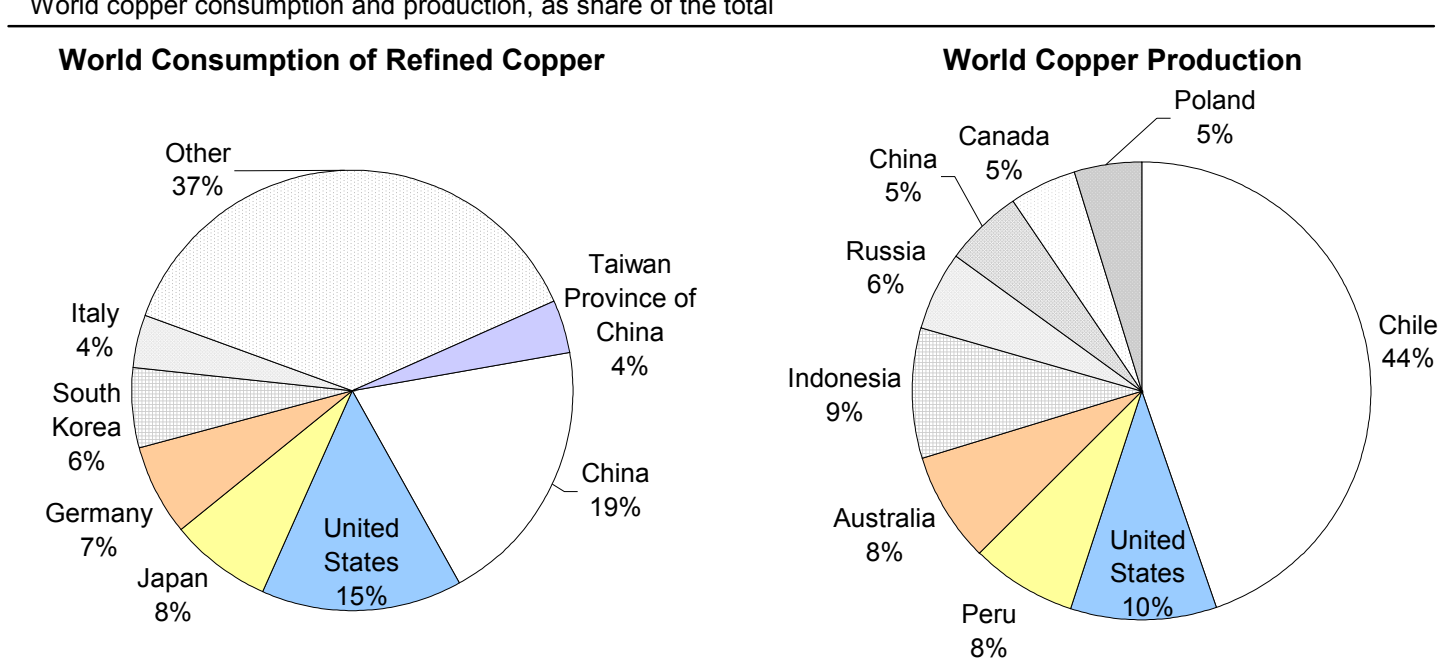

\footnotetext{
${ }^{1}$ Some analysts expect world demand to outstrip supply by about 450 million of tons in 2004 , bringing inventory levels below four week's worth of consumption, a level considered as the minimum operational inventory level for the industry.
} 


\section{Regional developments-especially Argentina's decision to cut natural gas} exports - are, however, weighing on activity. Recent positive economic developments have been overshadowed, in part, by Argentina's decision to reduce its natural gas exports to Chile. This is forcing domestic electricity generation to switch from relatively cheap natural gas to more costly coal- and diesel-generated power. At the same time, increases in petroleum import prices have raised costs further and dampened disposable income growth.

6. Growth has remained concentrated in selected sectors, dampening job growth. The economic rebound, to date, has been mostly in financial services, manufacturing, and retail trade. As a result, despite steady, albeit modest, job gains in personal and financial services, the unemployment rate remains at about 9 percent (Table, inset) and the negative output gap at 33/4 percent. Over the 12-month period ending in April 2004, the increase in nominal wages in the private sector was 3 percent.

Indicators of Economic Activity, 2002-2004

\begin{tabular}{|c|c|c|c|c|c|c|c|c|}
\hline & \multirow[b]{2}{*}{2002} & \multirow[b]{2}{*}{2003} & \multicolumn{4}{|c|}{2003} & \multicolumn{2}{|c|}{2004} \\
\hline & & & Q1 & Q2 & Q3 & Q4 & Q1 & Q2 \\
\hline \multicolumn{9}{|c|}{ (Percent change from corresponding period of previous year; unless otherwise indicated) } \\
\hline Real GDP & 2.2 & 3.3 & 3.5 & 3.0 & 3.0 & 3.0 & 4.1 & $\ldots$ \\
\hline Real domestic demand & 2.5 & 3.5 & 2.8 & 5.1 & 0.6 & 5.5 & 5.2 & $\ldots$ \\
\hline Net exports (contribution to growth) & -0.2 & -0.1 & 0.7 & -2.1 & 2.4 & -2.5 & -1.2 & $\ldots$ \\
\hline Output gap (percent of potential output) & -3.8 & -4.2 & -3.9 & -4.4 & -4.3 & -4.3 & -3.7 & $\ldots$ \\
\hline CPI inflation (12-month change) & 2.9 & 1.1 & 4.5 & 3.7 & 2.2 & 1.1 & -0.7 & 1.1 \\
\hline Employment (12-month change) $1 /$ & 1.1 & 2.9 & 3.0 & 3.9 & 2.8 & 2.7 & 1.4 & 1.2 \\
\hline Unemployment rate (percent of labor force) 1/ & 8.9 & 8.5 & 8.7 & 8.6 & 8.4 & 8.3 & 8.4 & 8.9 \\
\hline
\end{tabular}

1/ Data for employment and unemployment through May 2004.

Source: Haver Analytics and staff estimates. Quarterly data are seasonally adjusted.

7. Consumer spending has driven most of the recent pick up in activity. Consumption growth (proxied by real consumer goods imports) grew sharply in the first half of 2003, but paused in the second half. In more recent months, retail sales have picked up strength, largely fueled by lower interest rates, which have helped spur real consumer lending (Figure 2). Business investment, proxied by capital goods imports, also rose strongly in the first half of 2003, lost momentum in the second half of the year, and has been recovering in recent months (Figure 3 ). Businesses have been taking advantage of interest developments to refinance debt, locking in low interest rates and extending maturities.

Figure 2. Consumer spending \& borrowing

Real consumer imports and bank lending to consumers for personal loans and home mortgages

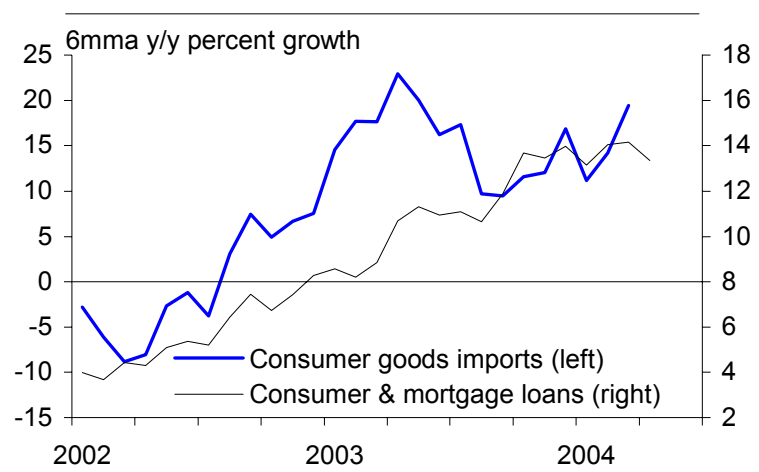


8. Reflecting in part a sharp appreciation of the peso, 12-month inflation temporarily fell below the inflation target range. The strong improvement in copper prices contributed to a sharp appreciation of the peso against the U.S. dollar beginning in mid-2003. ${ }^{2}$ In turn, the appreciation of the peso, together with the persistent output gap, led to downward pressure on domestic prices (Figure 4). In late 2003 and early 2004, twelve-month CPI inflation fell below the 2-4 percent central bank's inflation target range (Figure 5). Since February 2004, the peso has weakened somewhat against the U.S. dollar, and 12-month inflation has returned to a positive range-at 1 percent in June.

\section{In response to downward pressure} on prices, the central bank lowered its policy rate in late 2003 and early 2004. During most of 2003, the central bank kept its monetary policy rate unchanged at $23 / 4$ percent. However, following a sharp drop in expected inflation, ${ }^{3}$ the central bank cut its rate twice, by 50 basis points on each occasion, in December 2003 and January 2004. Since then, the rate has remained unchanged, well below most estimates of the neutral rate (Figure 6).

\section{Fiscal policy has remained prudent.} In 2000, the government introduced the fiscal structural balance rule - requiring the central government to maintain a cyclicallyadjusted surplus of 1 percent of GDP. Under the government's rule, noncopper revenue is adjusted over the business cycle
Figure 3. Business investment \& borrowing Real capital goods imports, lending to businesses, and the stock of corporate bonds (outstanding)

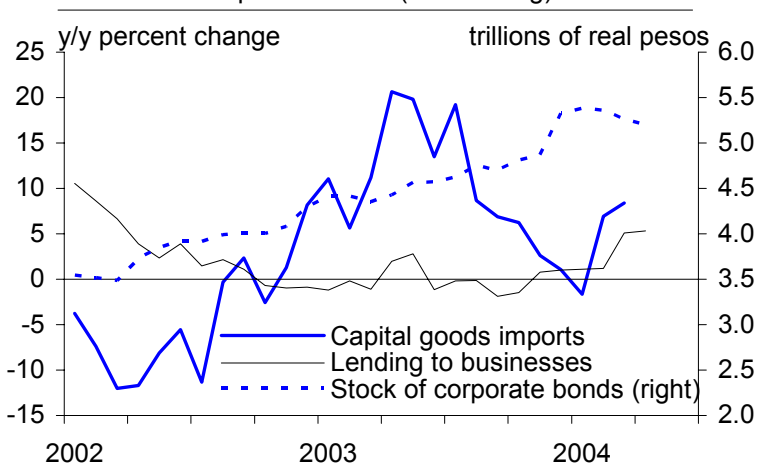

Figure 4. Inflation and the exchange rate

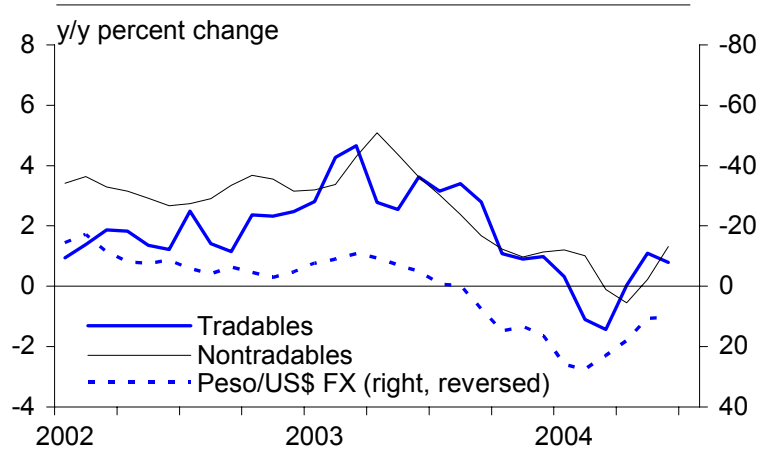

Figure 5. Inflation and the BCCh target band Headline and core CPI inflation

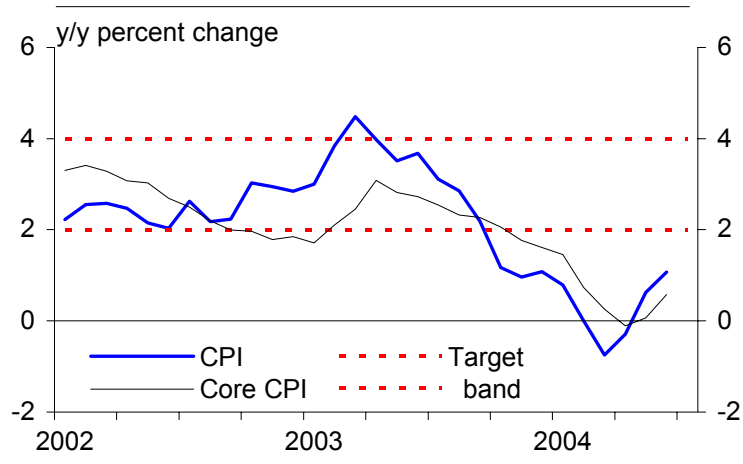

${ }^{2}$ During the second half of 2003, Chile's real effective exchange rate rose by close to 15 percent, before retreating by around 5 percent in the first five months of 2004.

${ }^{3}$ Expected inflation is calculated by taking the difference between the yields on the five-year nominal (BCP5) and five-year inflation-indexed (BCU5) central bank bonds, and through surveys of market analysts' expectations of future inflation. 
using an estimate of trend output, and copper revenue is smoothed out by assuming that revenue above (or below) a reference price is cyclical. Under this rule, which allows the government to effectively implement counter-cyclical policies, the actual deficit of the central government was reduced from $1 \frac{1}{4}$ percent of GDP in 2002 to $1 / 2$ percent in 2003 , primarily reflecting expenditure restraint (Tables 1 and 2).

Figure 6. Monetary policy and expectations

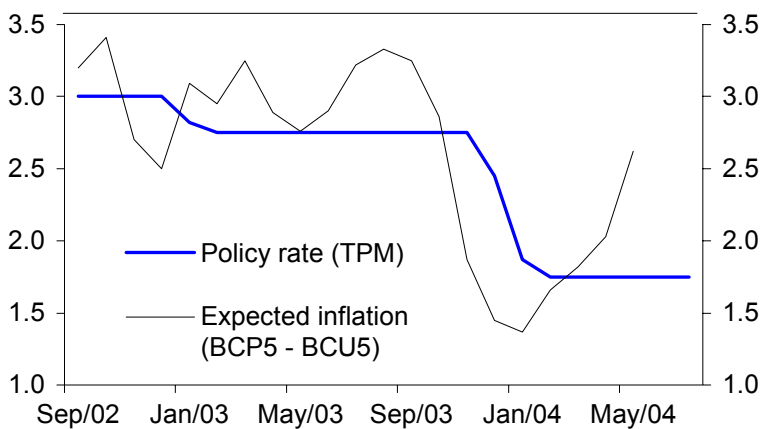

11. External conditions remain favorable, and vulnerability indicators have improved (Table, inset). In 2003, Chile's terms of trade improved by $43 / 4$ percent, reflecting in part the surge in copper prices, and the external current account deficit narrowed by $1 / 2$ percentage points, to $3 / 4$ percent of GDP. International reserves remain high — at about seven months of goods and services imports and nearly 20 percent of GDP - and comfortably exceed the stock of short-term external debt. The appreciation of the peso has also contributed to a significant reduction in the external debt-to-GDP ratio, although external corporate debt remains high (Appendix IV).

Vulnerability Indicators, 2000-2004

(in percent; unless otherwise indicated)

\begin{tabular}{|c|c|c|c|c|c|}
\hline & & & & & Proj. \\
\hline & 2000 & 2001 & 2002 & 2003 & 2004 \\
\hline \multicolumn{6}{|l|}{ Financial system } \\
\hline Foreign currency deposits / total deposits & 11.6 & 9.2 & 10.1 & 9.8 & $\ldots$ \\
\hline Net short-term for. assets of commercial banks, US\$ billion & 2.9 & 1.3 & 0.1 & -1.0 & -0.9 \\
\hline Nonperforming loans / total loans & 1.7 & 1.6 & 1.8 & 1.6 & $\ldots$ \\
\hline Risk-based capital-assets ratio & 13.3 & 12.7 & 14.0 & 14.1 & $\ldots$ \\
\hline \multicolumn{6}{|l|}{ Balance of payments } \\
\hline Current account (in percent of GDP) & -1.2 & -1.6 & -1.3 & -0.8 & 1.0 \\
\hline Short-term external debt (in percent of GDP) & 13.6 & 14.5 & 17.2 & 18.2 & 16.2 \\
\hline \multicolumn{6}{|l|}{ International reserves } \\
\hline In percent of GDP & 20.1 & 21.1 & 22.8 & 22.0 & 18.8 \\
\hline In months of imports & 8.5 & 8.3 & 7.8 & 6.9 & 6.8 \\
\hline In percent of short-term external debt & 147.6 & 144.8 & 132.4 & 120.7 & 116.2 \\
\hline
\end{tabular}

Sources: Central Bank of Chile, Haver Analytics, and Fund staff estimates and projections.

\section{REPORT ON THE DISCUSSIONS}

12. In the discussions, there was agreement that Chile is well-placed to benefit from the recovery of the world economy and undertake the structural reforms that would ensure sustained economic growth over the medium-term. Over a number of years, policy implementation in Chile has been largely congruent with the tenor of Fund advice (Box 2). The authorities noted that the Chilean economy rests on solid pillars, including: (i) a strong fiscal position with counter-cyclical capacity; (ii) a well-tested inflation targeting monetary policy in the context of a flexible exchange rate regime; (iii) a robust financial system; and 
(iv) a competitive, open economy. They concurred that short-term risks existed-largely external, but were confident that the challenges could be successfully addressed. The authorities were actively engaged in a rich public debate on the policies needed to sustain a high rate of economic growth over the medium term, with growing consensus on the need to reform the labor market and the educational system, promote competition, and improve income distribution.

\section{Box 2. Policy Recommendations and Implementation}

- Chile's policy implementation has been broadly consistent with the general thrust of Fund policy advice. In recent years, Fund advice has concentrated on steps to consolidate the country's accomplishments. In the area of fiscal policy, the Fund provided advice to enrich the structural balance rule, proposing reliance on a panel of experts to contribute to the forecast of copper reference prices and the output gap. More recently, the main focus has been on improving transparency, and the Chilean authorities have made considerable progress in migrating toward Fund standards. The staff has generally supported the authorities' approach on monetary policy and provided technical assistance on interest rate transmission mechanisms and monetary policy issues.

- On structural reform issues, the discussions have included the need to increase labor market flexibility and build further on Chile's impressive achievements in trade openness. The authorities concurred with the advice but progress in the labor area has been limited, in part because of institutional constraints. In the past, the Fund commended the authorities for the unilateral reduction of its uniform external tariff. Past missions have encouraged a phase out of price bands on certain agricultural products, and sugar and wheat are now the only two remaining products with (WTOcompliant) price bands.

- Chile's policies are also broadly consistent the Fund's standards and code initiatives. A fiscal ROSC was completed in 2003, and an FSAP was completed recently.

\section{A. Short-Term Economic Prospects and Risks}

13. The authorities and staff concurred that economic growth was expected to pick up to about 5 percent in 2004. Officials noted that the economy seemed poised for a rebound, thanks to a supportive external environment, monetary stimulus, and high copper prices. They expected the rebound in the global economy and the improvement in profit outlook to deliver a strong rise in investment in the second half of 2004. The output gap would close slowly, with economic growth moderately above trend, and inflation would gradually return to the central bank's target band, at about 2 percent by end-2004. ${ }^{4}$ Largely reflecting higher copper prices, the current account would register a surplus of 1 percent of GDP in 2004 (Table, inset).

\footnotetext{
${ }^{4}$ Trend GDP growth is estimated at 4 percent in 2004 and 41/4 percent over the medium term, down from $6 \frac{1}{2}$ percent in the $1990 \mathrm{~s}$, reflecting slower total factor productivity and employment growth.
} 
Medium-Term Baseline Scenario, 2003-2009

(in percent change from previous period, unless otherwise indicated)

\begin{tabular}{|c|c|c|c|c|c|c|c|}
\hline & 2003 & 2004 & 2005 & 2006 & 2007 & 2008 & 2009 \\
\hline Real GDP & 3.3 & 4.9 & $4 \frac{1}{2}-5 \frac{1}{2}$ & 5.3 & 5.1 & 4.8 & 4.3 \\
\hline Output gap & -4.2 & -3.3 & -2.4 & -1.3 & -0.5 & 0.0 & 0.0 \\
\hline Total domestic demand & 3.5 & 5.1 & 6.7 & 5.9 & 5.3 & 5.0 & 4.4 \\
\hline Private consumption & 3.7 & 4.1 & 6.6 & 5.8 & 5.5 & 4.6 & 3.8 \\
\hline Fixed investment & 4.8 & 8.5 & 9.0 & 8.5 & 8.0 & 8.0 & 8.0 \\
\hline Unemployment rate (percent) & 8.5 & 8.3 & 8.0 & 7.8 & 7.8 & 7.7 & 7.7 \\
\hline Consumer price index (end of period) & 1.1 & 2.1 & 2.9 & 3.0 & 3.0 & 3.0 & 3.0 \\
\hline Terms of trade & 4.8 & 11.1 & -3.9 & -3.7 & -1.5 & 1.5 & 0.2 \\
\hline Copper prices (US $\not / l \mathrm{lb})$ & 80.7 & 122.5 & 104.3 & 90.7 & 86.2 & 88.5 & 89.6 \\
\hline \multicolumn{8}{|c|}{ (In percent of GDP) } \\
\hline Central government balance & -0.5 & 1.5 & 1.2 & 1.1 & 1.1 & 0.8 & 0.8 \\
\hline Central government gross debt & 13.3 & 12.0 & 11.9 & 11.1 & 10.6 & 9.5 & 8.8 \\
\hline Current account & -0.8 & 1.0 & -0.9 & -1.9 & -2.4 & -2.6 & -2.8 \\
\hline Gross external debt & 60.1 & 51.0 & 48.2 & 48.5 & 49.3 & 50.1 & 51.1 \\
\hline Public & 12.9 & 10.5 & 9.5 & 8.7 & 7.5 & 6.4 & 5.6 \\
\hline Private & 47.3 & 40.5 & 38.8 & 39.8 & 41.8 & 43.7 & 45.6 \\
\hline
\end{tabular}

Sources: Central Bank of Chile; Ministry of Finance; and Fund staff projections.

\section{The authorities viewed the risks to the short-term outlook, largely stemming from}

external sources, to be manageable. There was agreement that a sharp increase in world interest rates and oil prices could weigh on growth, dampening both domestic and external demand and making external financing conditions more difficult. However, the authorities were confident that the economy could weather these risks with relative ease. ${ }^{5}$ They recognized the risks of lower copper prices, especially in the event of weaker-thananticipated global activity, but noted that these risks were modest given the low level of world copper inventories. ${ }^{6}$ The impact of higher interest rates abroad would also be relatively small, given that external public debt is low and that private corporations have taken advantage of low interest rates to restructure debt. The authorities expected the disruption of natural gas supplies from Argentina to remain sporadic and estimated that, in a worst case scenario, output growth would be reduced by about 0.1 percent in 2004 . They also noted that the issue should be resolved by end-2005, as several new power plants would be completed, relieving pressure on the electricity grid, while the new electricity law would gradually encourage additional investment in the electricity sector (Box 3).

\footnotetext{
${ }^{5}$ Chile imports most of its oil, and a sensitivity analysis shows that a 10 percent increase in oil prices would reduce the 2004 external current account surplus by about $1 / 2$ percent of GDP.

${ }^{6}$ A moderate decline in copper prices would have a limited direct impact on the economy. In the corporate sector, profits would move closer to long-term levels, which would negatively affect investment. In the public finances, the surpluses accrued to the Copper Stabilization Fund would be reduced but, given the structural balance rule, lower prices would not impact on long term fiscal health.
} 


\section{Box 3. Energy Policy}

- Since 1997, Chile has increased its reliance on gas-fired power generation plants and, correspondingly, its dependence of gas imports from Argentina. By 2003, gas-fired plants supplied about 40 percent of total electricity demand, with gas imports from Argentina accounting for 98 percent of the gas supply. Given their cost effectiveness, gas-fired plants rapidly displaced coal and diesel plants, especially in northern Chile, home to the vast majority of the mining industry, providing more than 60 percent of power generation in this region.

- In early April, Argentina announced a unilateral cut in natural gas exports to Chile. The cut, of 15 percent initially, was raised to 40 percent in May, but reduced to 15-20 percent in mid-June. These cuts are expected to be temporary, and thus unlikely to have a major impact on the economy. In the short run, power generation firms are meeting electricity demand by bringing existing coal and dieselfired plants back online, albeit at significantly higher costs. Newly installed hydroelectric capacity is also expected to help ease supply.

- The increased vulnerability of energy supply from Argentina and the need to speed up investment on power generation in coming years raise questions on the development of the electricity sector. Deeper and prolonged cuts could become a significant source of risk. Power consumption in the central region of the country is expanding rapidly as the economy rebounds, and the situation could become more difficult in the case of a harsh winter. A 2003 report noted that expected electricity demand growth would put significant strain on the projected supply capacity, especially during dry years.

- A new electricity law (Ley Corta) was approved in early 2004, aimed at increasing electricity generating capacity and improving transmission systems. The law promotes the interconnection of existing networks and changes the fees paid by generation and distribution companies to transmission companies. In an effort to end disputes between companies, transmission fees are no longer to be negotiated between transmission and generation companies in individual contracts. The law also aims at stabilizing node prices by allowing a fluctuation of up to 5 percent from the market price negotiated in private contracts (down from 10 percent previously). The new law also establishes the creation of a panel of experts to mediate disputes among companies, and between them and the authorities. The new law is expected to boost investment in electricity generation by reducing regulatory uncertainty.

\section{B. Fiscal Policy and the Structural Balance Rule}

15. The structural balance rule has successfully anchored fiscal policy. The rule targets a cyclically-adjusted surplus of 1 percent of GDP in the accounts of the central government, designed to broadly offset the quasi-fiscal losses of the central bank of $1 / 2-1$ percent a year (Figure 7). In order to help comply with the rule, in 2003 the authorities took strong action to trim spending, and they raised the value-added tax rate from 18 percent to 19 percent to help compensate for the loss of revenues from Chile's free trade agreements with the United States and the EU. Chile's overall fiscal performance compares favorably with that of the OECD countries (Box 4).

Figure 7. Central government fiscal balance

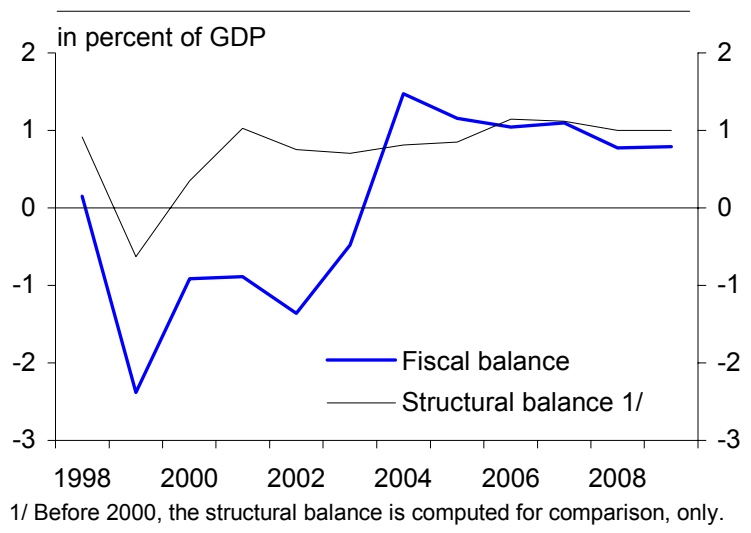




\section{Box 4. Fiscal Balance: Comparison with OECD Countries}

- Chile's fiscal stance is prudent by international standards. In recent years, its fiscal deficit has remained well-contained, at around $3 / 4$ percent of GDP. This deficit is a full percentage point lower than the OECD average for industrialized countries, and four percentage points lower than the average for the six emerging market members of the OECD.

- The size of the public sector is relatively small in Chile. At just under 25 percent of GDP, general government expenditure is below the average for the emerging market members of the OECD (32 percent). Total general government revenue is also at a relatively moderate level, equivalent to about 24 percent of GDP (with a tax-toGDP ratio close to 18 percent). Chile's revenue ratios are also lower than the OECD average for emerging market economies, which is of about 27 percent.

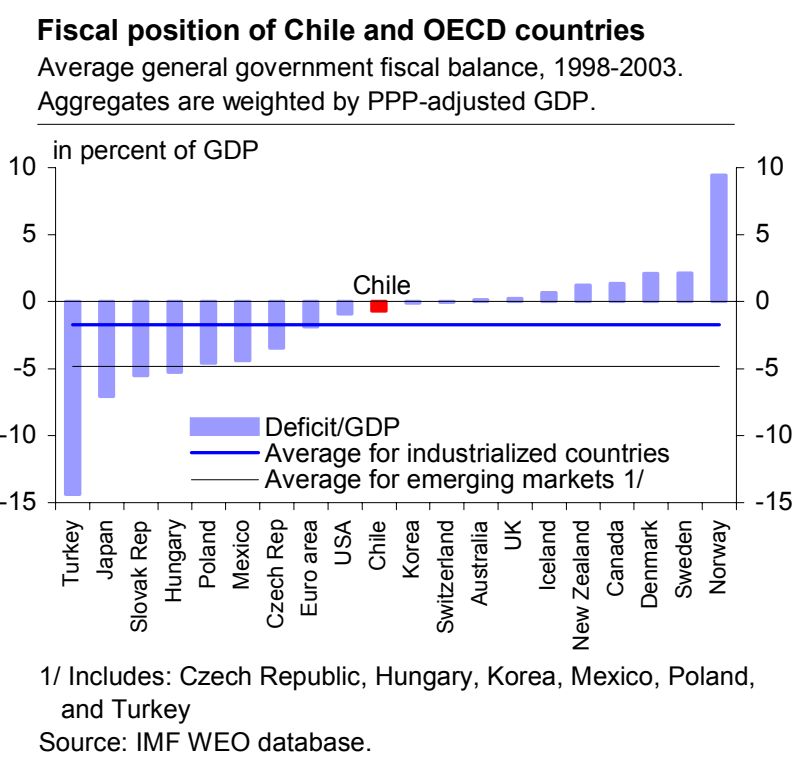

16. The government has reaffirmed its commitment to comply with the fiscal rule in 2004 and to continue resisting pressure to increase spending. The authorities noted that the fiscal expenditure stance would remain cautious and, thus far, they have been successful in resisting pressure to increase spending and extend subsidies on domestic petroleum products. Beginning in 2004, the budget includes special funds for the military as part of the structural balance. ${ }^{7}$ To that effect, revenue accruing to the military-which includes 10 percent of the sales of the state copper company CODELCO (estimated at $1 / 2$ percent of GDP in 2004) — can only be spent with the prior authorization of both the defense ministry and the budget office. This commitment to fiscal prudence has not come at the cost of social programs; instead, recent social spending has been higher than in the late 1990s (Table 3).

\section{The mission enquired about prospects for entrenching the structural balance rule} over the medium term. The staff noted that the authorities' commitment to the structural balance rule had given substantial credibility to their fiscal policy; however, this rule was not embodied in law. The authorities concurred that the rule had achieved considerable support and anticipated that the next administration would maintain it - perhaps with relatively limited changes. In coming months, the government plans to introduce legislation to require future budgets to include an indicator of the structural balance. This would, in their view, help further formalize the fiscal rule, and the mission encouraged the authorities to take further steps toward institutionalizing this rule.

\footnotetext{
${ }^{7}$ Under Ley Reservada 13.196, the military receives transfers from CODELCO equal to 10 percent of its copper sales. Until the 2004 budget, these revenue and expenditure data were not published.
} 
18. The authorities are prudently using the resources accrued to the Copper Stabilization Fund (CSF) to pay down debt. Assuming an average copper price of US\$1.20 a pound, the CSF is expected to accumulate resources of US\$1-1 1/2 billion in 2004 . The government is planning to use a significant part of these resources to prepay expensive debt. During January-April 2004, the government pre-paid US\$335 million in debts to the World Bank and the Inter-American Development Bank.

19. The authorities offered a spirited defense of their plans to impose a fee on private mining companies. Although not yet final at the time of the consultation discussions, its main feature would be the imposition of a $0-3$ percent fee on the profits of mining companies. They considered that, while academic work pointed to the need to tax nonrenewable resources, most mining companies had, in practice, avoided paying taxes, in part thanks to accelerated depreciation rules. The staff concurred, but noted private sector concerns that the government might be retreating from an implicit guarantee not to increase taxes on foreign mining companies for a period of up to twenty years after investments have taken place. The staff, therefore, advised the authorities to only impose the fee on new investments, to avoid any impression of a change in the rules of the game. The authorities noted the difficulty of changing tax laws and distinguishing old investments from new ones. They explained that they were preparing a modified plan with a three-year transition period, under which the fee would only be binding for new investments. The authorities plan to use the annual proceeds from the fee-expected to be small, at about $1 / 4$ percent of GDP - to help promote technological and scientific innovation.

20. The authorities welcomed the opportunity to participate in a pilot project evaluating public investment. They noted that they had a long and successful track record of using Public-Private Partnerships (PPPs). Overall, infrastructure investments under the PPP framework had amounted to close to US\$6 billion over the past ten years, with contingent liabilities for the government of about US\$1 billion. The authorities welcomed further work with Fund staff on public investment and fiscal policies.

21. The officials also welcomed further assistance in compiling fiscal statistics, but reiterated their long-standing views of some international standards. Starting with FY2004, the authorities published the budget using most of the methodology in the Fund's Government Financial Statistics Manual (GFSM). However, full migration will not be achieved until the central bank is recapitalized. The authorities also concurred that other discrepancies persisted between the official data and GFSM, related to inflation and dollarindexed debt (Appendix III), and agreed to publish a chapter in the FY2005 budget to outline the issues. The officials also welcomed further STA technical assistance in that area. 
22. The Debt Sustainability Analysis (DSA) shows that Chile's debt is resilient to

shocks. With the structural fiscal rule, the net public debt-to-GDP ratio is projected to gradually decline over the medium term, from already low levels to about 10 percent of GDP by 2009 (Figure 8 and Appendix IV). The external debt of the private sector is relatively high, but there are mitigating factors to external vulnerability, including the presence of natural hedges for the export sector and access to financial hedges. Shortterm debt on a residual maturity basis represents only 22 percent of private sector external debt, and the average duration of medium-term debt is above five years. More than half of private external debt is owed by

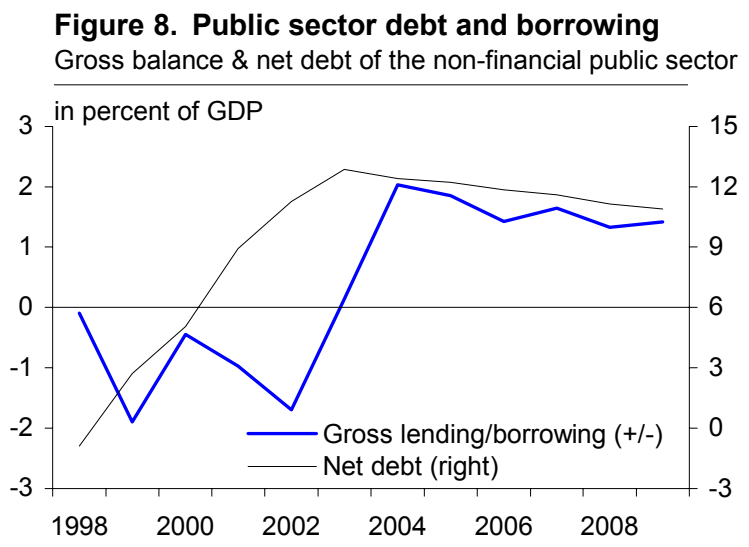
foreign-owned firms, with one third of this debt representing the claims of parent companies.

\section{Maintaining a Strong and Credible Monetary Policy Framework}

23. The authorities and the mission concurred that inflation targeting has successfully helped guide inflationary expectations. Since May 2000, the objective of the central bank's inflation targeting framework has been to keep CPI inflation within the 2-4 percent range (Figure 9). In this framework, the authorities adjust the monetary policy rate whenever the inflation rate is projected to deviate persistently from the mid-range of the target band. The central bank considers that price developments are guided by: (i) the output gap; (ii) trade margins and costs, including exchange rate developments; and (iii) price expectations. An effective communication

Figure 9. Inflation expecations and monetary policy Inflation forecasts from surveys and the difference between inflation-indexed and nominal bonds.

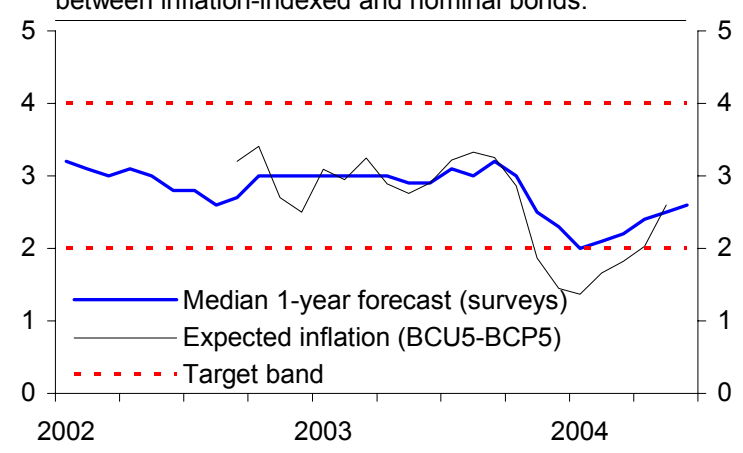
strategy has been key to the transparency of the monetary policy design in Chile (Box 5).

24. The monetary authorities reaffirmed their commitment to maintaining inflation close to the mid-point of the 2-4 percent target range. They consider that well-anchored expectations are key to ensuring effective countercyclical policies and remarked that the inflation objective of the central bank was well-accepted and understood by the general public. Although monetary policy had continued to be stimulative, the central bank was carefully monitoring the appropriate time to withdraw stimulus; the output gap was still large; the outlook for oil prices uncertain; and there was evidence that the Chilean core CPI indicator was gradually converging, from below, to the official target band. The authorities reaffirmed their readiness to move decisively whenever conditions would indicate that a tightening of monetary policy is needed. 


\section{Box 5. Central Bank Communication Strategy}

In an inflation targeting framework, communication is key. The periodic communication of the central bank's inflation objectives, as well as its views about the economy, helps generate public understanding of the central bank's policies, hence increasing the credibility of the policy, anchoring inflation expectations and, in turn, facilitating price stability. An important component of this communication strategy is the central bank's Monetary Policy Report published three times a year.

$A$ recent study evaluates the effectiveness of cross-country inflation reports. In a recent assessment, Fracasso, Genberg, and Wyplosz (2003) $)^{1}$ suggest that a good report should: (i) contain a concise but complete executive summary, and a discussion of special topics; (ii) provide continuity for the reader's ease and be transparent about the assumptions behind key macroeconomic variables and the forecast of inflation; and (iii) present the risks associated with the forecast. The Bank of England's report sets the standard on all the categories used in the ranking, while Chile ranks fifth. The report stresses the need to keep the general public well informed and minimize market surprises.

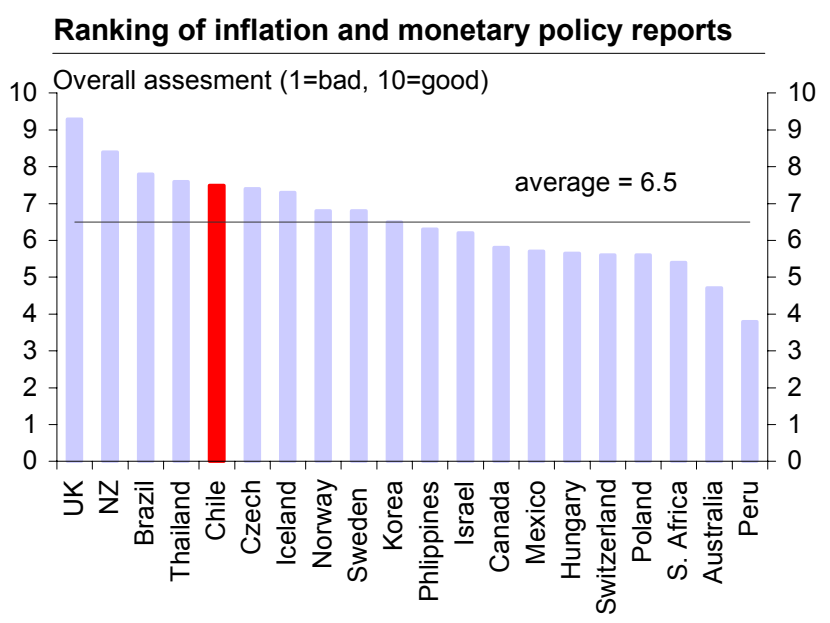

Several communication outlets contribute to the transparency of the monetary policy design in Chile:

- A communiqué is released at the conclusion of the monthly bank's Board of Directors policy meeting which, in turn, is announced six months in advance.

- The Minutes of the monthly policy meetings of the Board of Directors are released within 3 weeks.

- The central bank testifies once a year before the full Senate and twice before the Finance Committee. The central bank also meets frequently with the private sector to discuss the inflation outlook.

- The central bank publishes its Analysts' Forecast Survey (including inflation, GDP growth, interest rates, and exchange rate forecasts) on a monthly basis, and a survey on credit conditions on a quarterly basis.

- The presentations made by the central bank's authorities before different forums are posted on the central bank's web page. The bank publishes all relevant economic and financial data as soon as they become available.

- The central bank regularly publishes high caliber economic policy and working papers. It has released a description of the structural and auxiliary models used in its inflation forecasting and policy research.

1 "How Do Central Banks Write? An Evaluation of Inflation Reports by Inflation Targeting Central Banks" by A. Fracasso, H. Genberg, and C. Wyplosz (2003), Norges Bank.

\section{The mission commended the authorities for their flexible exchange rate policy.}

Since the beginning of 2003, the peso has displayed significant volatility, largely reflecting changes in the external environment. From mid-March 2003 through mid-January 2004, the peso appreciated by about 23 percent against the U.S. dollar, but it has since then depreciated by close to 11 percent (Figure 10). The economy seems to have coped well. There is growing evidence that the market for foreign exchange hedging has deepened, with sectors long in 
foreign currency (including pension funds, which hold about 27 percent of their assets abroad) offering hedges to other sectors. Chile's external competitiveness remains sound, as evidenced by the strong growth in nontraditional exports; nonmining exports rose by 17 percent in the year through June 2004.

26. The mission was supportive of the central bank's debt management strategy and its recent dollar-debt redemption program. Recently, the central bank moved to standardize and modernize the issuance of its debt instruments, which has helped promote liquidity of central bank debt and the development of a fixed-income corporate bond market. The bank has also announced that it will take steps to promote longer-term (ten-year) nominal peso bonds. In November 2003, the central bank announced that it would aim at gradually reducing the stock of its dollar-indexed debt, while concomitantly lowering its gross reserves level (Figure 11). This

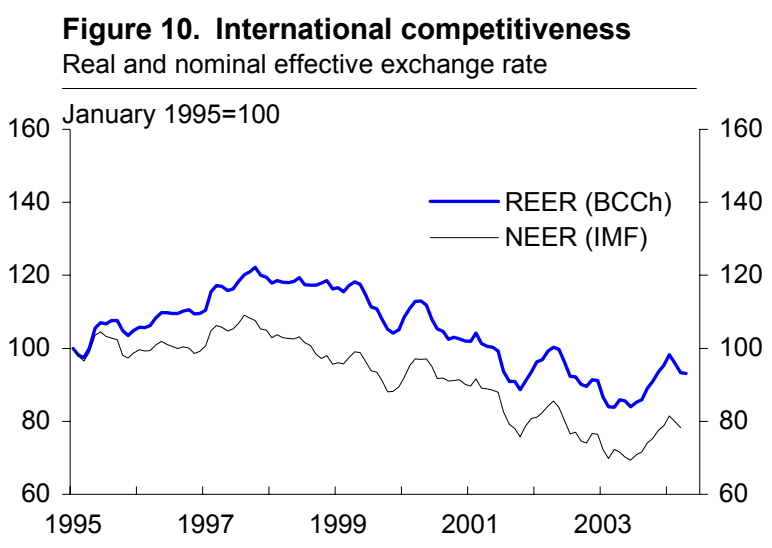

Figure 11. Stock of central bank paper Distribution of debt, evaluated at end of period exchange rates.

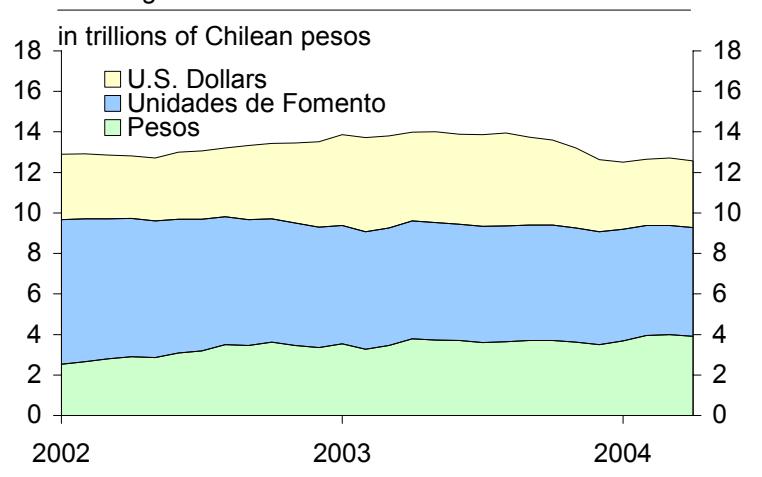
policy, which would help reduce the central bank's quasi-fiscal losses, does not entail intervention in the foreign exchange market - given that the net foreign exchange position would remain unchanged. The staff concurred that there was some scope for a reduction in the stock of dollar-indexed debt, given the comfortable level of gross official reserves. ${ }^{8}$ However, the mission advised the authorities to move prudently and avoid too large a decline in gross reserves, as this could adversely affect market perceptions and confidence. The authorities concurred, noting that they would keep their plans under review, based on financial market developments.

\section{The mission inquired about the status of the recapitalization of the central bank. ${ }^{9}$}

The authorities reaffirmed their willingness to recapitalize the central bank. They explained

\footnotetext{
${ }^{8}$ More details are presented in the paper on the Optimal Level of Reserves in the companion Selected Issues Papers.

${ }^{9}$ The recapitalization of the central bank, which has long been part of the Fund's advice, is needed to eliminate the central bank's operational deficit. The origins of this deficit can be traced to the support provided during the banking crisis of the early $1980 \mathrm{~s}$, and to the financing of foreign reserves accumulation during the early 1990s. The deficit also reflects a central government policy of paying only part of the accrued interest of its debt held by the central bank.
} 
that the finance ministry and the central bank had made good progress toward the technical work in this area. However, they noted that the recapitalization would impact the central government accounts, thus forcing a redefinition of the structural balance rule. In the meantime, as a first step, they planned to advance the repayment of government debt held by the central bank, to help reduce its quasi-fiscal losses.

\section{Enhancing the Strength of the Financial Sector}

28. The authorities welcomed the conclusions of the recent FSAP and expressed strong confidence in the soundness of the banking system. The FSAP team found the Chilean banking sector sound and well-regulated and supervised (Box 6). They noted that an efficient allocation of resources will require enhancing competition in financial services, filling some gaps in market infrastructure, and adapting the oversight framework to meet the needs of an increasingly integrated and complex financial system. They also pointed out the need to address issues in the insurance sector, including some under-provisioning of risks. The authorities were in broad agreement with the findings of the FSAP and indicated that they would follow up on its main recommendations. Improved financial conditions and a deeper financial market have helped create the conditions for strong economic growth. In 2003, bank lending increased sharply; corporate bond issuance reached record levels; and the equity market showed signs of renewed activity. With debt leverage for firms and consumers still low by historical and international standards, the authorities expected further credit growth, spurred by still low domestic interest rates and improving economic conditions.

29. The mission acknowledged the strength of Chile's financial system, and commended the authorities for their efforts to move toward risk-based regulation and supervision. Chile's supervisory and regulatory regime is strong and well-established. The transition to a more risked-based supervision, however, would require increasing efforts to improve disclosure standards and bank management, particularly for securitization and derivatives. The mission proposed easing bank restrictions on options markets, which would provide a boost to the development of derivatives markets and allow a more efficient allocation of risks. With the increasing sophistication of financial markets and corporate sector, staff also underscored the need to continue promoting the analytical and technical expertise, as well as the information processing capabilities, of supervisors and regulators.

30. Declining credit risk, measured by lower delinquency rates, has helped push down sharply the nonoperational costs of banks, providing a boost to net income. At the same time, increased competition in consumer and large corporate lending, together with improving bank efficiency, is contributing to a substantial narrowing of margins. As a result, banks are stepping up their efforts to diversify their revenue sources into commission-based activities. The authorities also noted that, with corporate profitability and consumers' personal income increasing, borrowers should have room for additional borrowing without compromising their repayment capacity. 


\section{Box 6. Financial System Stability Assessment (FSSA): Summary of Findings}

- The Chilean banking system was found to be sound, generally resilient to shocks, and wellsupervised. Banks are well capitalized, profitable, internationally integrated, and have relatively low nonperforming loans. Stress tests indicate that they would absorb sizable macroeconomic shocks with only a moderate impact on their solvency. Although bank competition remains limited, it has increased significantly in recent years.

- Private pension funds are by far the dominant institutional investors in the country. There is room to enhance their impact on the domestic financial system by a judicious relaxation of their overly restrictive investment regime without undermining their fiduciary function. In addition, current efforts to enhance competition in the industry should be intensified, and a more radical reform considered to unbundle pension-related services that are subject to economies of scale (such as contributions collection, accounts management, and payouts to retirees) from those services where price competition can thrive (asset management). The insurance sector faces some under-provisioning of risks, increased competition, and weaknesses in its resolution framework. The needed increase in provisions and reforms to the supervisory framework should be carefully planned and phased in.

- Some important gaps in market infrastructure that limit market liquidity and investment need to be filled. This will require embedding more firmly in the law key concepts underlying securities clearance and settlement, organizing a market for securities lending, introducing multilateral netting arrangements, and formalizing the system of market makers. Valuation methods and contract standardization in securities markets and disclosure in the OTC market need to be improved. International financial reporting standards for listed firms should be introduced and a review of financial sector taxation conducted.

- The current segmented financial oversight has functioned adequately so far but should adapt to the needs of an increasingly integrated and complex financial system. Reforms should focus, in the short term, on enhancing cooperation among regulators and filling the gaps in systemic market surveillance. For the medium term, legal changes will be needed to support the fully consolidated supervision of financial conglomerates. This move should be accompanied by further progress from rule-based to risk-based supervision, coupled with a strengthening of the financial and legal autonomy of the supervisory agencies and enhanced accountability.

- The AML/CFT framework needs strengthening by: (i) addressing the limited sanctioning powers of the Financial Intelligence Unit and its inadequate access to information; and (ii) extending the range of application of AML/CFT to foreign exchange operators, securities firms, and insurance companies.

31. Officials viewed the proposed reform of the capital markets (Capital Market II) as another step toward promoting further bank competition and broadening the development of domestic capital markets. The proposal provides strong incentives for the development of the venture capital industry, which is expected to help small- and medium-sized enterprises gain readier access to capital (most of their financing, thus far, has been from the government-owned Banco Estado and the specialized fund CORFO). The reform also includes provisions to standardize pledges on collateral and create a national registry of pledges. A number of initiatives also seek to strengthen regulation and supervision, including improving operating standards in the securities industry, broadening the powers of the supervisory agencies, and increasing information-sharing across agencies. The authorities emphasized that the reform proposal also incorporates some key recommendations of the recent Corporate Governance ROSC to align corporate law with OECD standards. 
32. The mission welcomed the authorities' consideration of proposals to foster worker participation and asset management competition in the private pension system. The system has undergone extensive consolidation in recent years, with the number of funds reduced from 21 in the mid-1990s to only six funds in 2004. The authorities pointed to three key challenges for the system:

- Increasing the coverage of individual accounts, as less than half of the affiliated workers contribute on a regular basis and are eligible for a minimum pension (minimum pensions require a total of 20 years of contributions);

- $\quad$ Reducing operational costs, which remain high by international standards; and

- Increasing asset management competition, as the current regulatory regime is somewhat restrictive and cumbersome.

Staff agreed that the recent creation of the voluntary pension system in which all financial intermediaries can compete should enhance competition in the pension industry. Nonetheless, the mission encouraged the authorities to outsource operational management services and to rationalize the investment regime, with a view to allowing greater diversification of funds.

33. Officials agreed that Chile's $A M L / C F T$ framework requires further adjustments to be in line with international standards. Chile is a member of GAFISUD, the regional intergovernmental organization which brings together the countries of South America in order to combat money laundering and terrorism. In its 2003 report, GASFISUD commended the Chilean authorities for the creation of a Financial Intelligence Unit (FIU) and for stepping up disclosure requirements by financial institutions. However, subsequent rulings of the Constitutional Court reduced the sanctioning powers of the FIU and denied it access to information protected by bank secrecy. The authorities have recognized these shortcomings, and are considering steps to address them. They have also agreed to allow publication of the AML/CFT ROSC on the Fund's website.

\section{E. Sustaining Strong Economic Growth into the Medium-Term}

34. Attention is being focused on the agenda to sustain strong growth over the medium term. To rekindle Chile's economic growth, which has slowed to $2 \frac{1}{2}$ percent a year on average since 1998, the authorities are implementing the Pro-Growth Agenda - a set of reforms intended to address various constraints on growth and reduce regulatory uncertainty in key sectors of the economy. In recent months, congress has approved several of the reforms included in this agenda (Appendix V). The authorities stressed that the benefits of the reforms implemented in the last two decades would continue to be felt for at least a few more years. However, they recognized that further reforms were needed to sustain strong productivity and growth beyond then, including through continued trade liberalization, labor reform, and improvements in health and education. 


\section{External markets}

\section{The mission commended the authorities for helping advance trade liberalization.}

In 2003, Chile's external tariff rate averaged only $2 \frac{1}{2}$ percent, among the lowest in the world. Chile's ambitious effort to negotiate bilateral free-trade arrangements (FTAs) meant that more than 90 percent of Chilean export products benefited from preferential treatment in export markets, with the recently implemented FTAs with the European Union and the United States expected to have significant positive effects on growth over the medium term. Although the authorities underscored their strong support for the Doha Round, they also indicated their continued interest in additional bilateral trade agreements. Following the completion of negotiations with South Korea, the authorities were planning new bilateral agreements with several Asian countries including: (i) a closer cooperation agreement with New Zealand and Singapore to improve products' competitiveness in third markets; (ii) a broad FTA with China; and (iii) a trade liberalization agreement with India for a limited list of products.

36. The authorities underscored that Chile's foreign investment platform provides one of the world's most open regimes, as well as a stable legal framework. ${ }^{10}$ Chile has no financial account restrictions, except for the one-year residency requirement for the equity portion of investment under Decree Law 600, a nonmandatory agreement with foreign investors. The authorities noted that the investment chapter in the U.S. FTA included far-reaching requirements in the areas of intellectual property and financial services. While recognizing the authorities' efforts to reach double taxation agreements with major investment partner countries, staff noted that market participants, at times, expressed concerns about the excessive complexity of domestic taxation rules for foreign portfolio investors.

\section{Labor market, Education, and Income Inequality}

37. Chile's economy would benefit from increased labor flexibility. Two recent studies show that Chile's labor market is less flexible than those of Canada, New Zealand, and Korea, but somewhat more flexible than those of some European countries. ${ }^{11}$ Although Chile's unemployment rate continues to show a downward trend, it remains relatively high (Figure 12). The

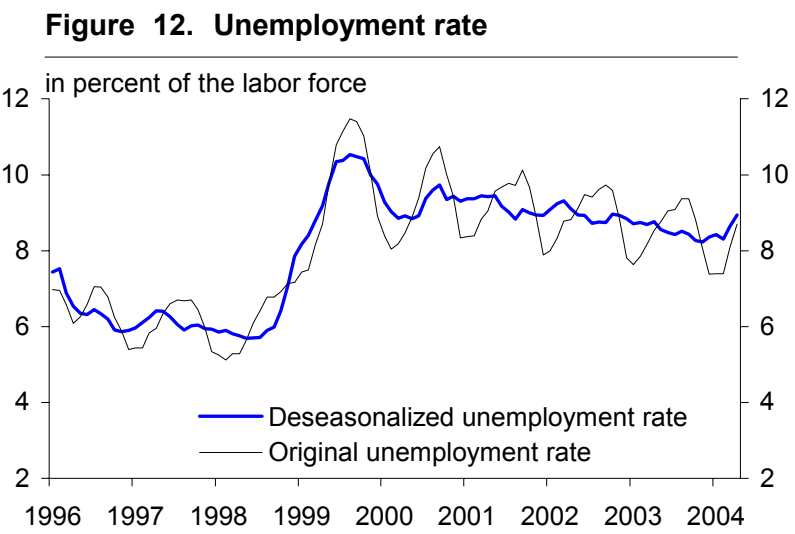

\footnotetext{
${ }^{10}$ According to the OECD, only the United Kingdom and Ireland have a lower measure of FDI restrictiveness than Chile. In particular, Chile has no investment restrictions in sensitive sectors such as finance, telecommunications, and electricity.

11 "Labor Market Dynamics in Chile: An International Perspective" by Albagli E., P. García and J. Restrepo-Seventh Annual Conference of the central bank of Chile on Labor Markets and Institutions, November 2003; and OECD Economic Surveys: Chile, Chapter IV, November 2003.
} 
authorities agreed that more flexibility should be introduced in the labor market. Specifically, current limits on hours worked, the length of standard labor contracts, high dismissal costs, and limits on part-time employment hamper the development of the Chilean labor market. However, legislation to introduce more flexibility continues to face stiff opposition from labor unions, making passage unlikely in the short-term. The authorities agreed with the staff that any increases in the minimum wage would have to be consistent with the objective of preserving competitiveness and employment.

\section{The authorities see improvements in education as central to raising total factor}

productivity and reducing income inequality. There is some evidence that the education voucher system introduced in Chile in 1980 has led to some improvement in quality, but this program is generally seen as costly, poorly supervised, and lacking in efficiency. Although the average years of schooling has increased from $83 / 4$ years in 1990 to $10 \frac{1}{2}$ years in 2002, the OECD's measurement of average proficiency in reading, mathematics, and sciences for 15 -year old students is low by international standards. In addition, large quality differences persist across socio-economic sectors, and only 30 percent of high school graduates attend college. The authorities are seeking improvements in the qualification requirements and salaries of teachers. Some elements of merit pay were introduced in 1994, but they need to be broadened and a new system of accountability and incentives introduced. The authorities also indicated that they plan to promote broader access to tertiary education through loans and subsidies. The government also intends to press ahead with a program to expand and rationalize research and development spending. ${ }^{12}$

\section{Reflecting in part the benefits of strong economic growth, poverty has been cut in}

half since 1990 (Figure 13). The authorities have recently introduced a new program, Chile Solidario, aimed at addressing some of

the shortfalls of previous poverty reduction programs. Chile Solidario is well-targeted and aims at lifting the extremely poor into the mainstream without generating dependency (its maximum duration is two years). To that effect, targeted groups are coached by trained counselors, who explain the social benefits of the program, and transfers to beneficiaries are tied to clearly articulated, step-by-step, self-help programs. Progress is being made in meeting Chile's Millennium Development Goals (Table 9).

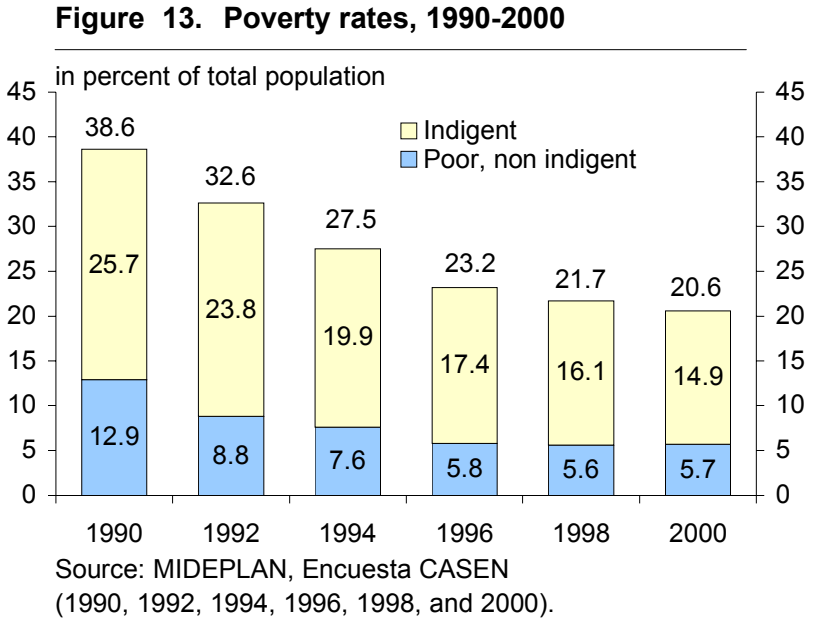

${ }^{12}$ According to the OECD, total research and development spending is equivalent to only $1 / 2$ percent of GDP — well below the OECD average of $2 \frac{1}{2}$ percent of GDP. 


\section{Staff APPRAisal}

40. The Chilean authorities are to be commended for the continued implementation of well-designed policies. Their adherence to prudent fiscal policies together with the successful implementation of the inflation targeting framework are noteworthy. The prudent macroeconomic stance and strong economic institutions have effectively led to sustained economic growth and a sharp reduction in poverty. In 2004, real GDP growth is projected to gather further momentum, while inflation would gradually return within the inflation target band. Reflecting the global recovery, copper prices have remained high and are expected to help generate a surplus in the current account balance in 2004.

41. In recent years, the fiscal rule has gained considerable credibility, reflecting the authorities' firm commitment to prudent fiscal policy. The staff encourages the authorities to take further steps toward institutionalizing the rule and secure the necessary consensus to ensure that it is preserved over the medium term. Staff welcomes Chile's decision to participate in a pilot program on public investment and fiscal policies.

42. The inflation targeting framework is working well. The low levels of 12-month CPI inflation registered in early 2004 largely reflected the earlier appreciation of the peso, and surveys show that the core CPI is gradually returning to the center of the inflation target band. The central bank has effectively communicated its policy, and thereby helped anchor inflation expectations.

43. The strengths of the policy framework should help Chile weather well the largely external risks to the outlook. The long-delayed recovery in investment now seems well under way and conditions are in place to sustain strong output growth into 2005. The expected increase in global interest rates, high prevailing oil prices, and the issues associated with the supply of gas constitute risks, but they appear manageable.

44. The current stance of monetary policy is appropriate. Given the persistent output gap and inflation expectations anchored at the middle of the target range, monetary policy could support domestic demand for some time. The authorities' readiness to raise interest rates as soon as required by domestic and external conditions is appropriate.

45. The staff supports the central bank policy of nonintervention in the foreign exchange market. External competitiveness is appropriate, as evidenced by the strong growth of nontraditional exports.

46. The FSAP team concluded that the financial system is strong, while recommending a number of measures to enhance it further. Staff appreciates the authorities' intention to follow the FSAP recommendations closely, to help further improve the depth of the financial system and the competitiveness of the banking system.

47. Although the proposal to introduce a fee on mining companies has gathered broad popular support, staff would encourage caution in that area. Any change in the taxation of 
mining companies would have to be prepared carefully to ensure that it does not interfere with investment guarantees and increase investor uncertainty.

48. Staff encourages the authorities to continue their work toward the recapitalization of the central bank. While, in a first stage, steps are expected to be taken to reduce the stock of government debt held by the central bank, the objective of recapitalizing the central bank should continue to be actively pursued.

49. Chile's emphasis on free trade is commendable. The recent free trade agreements with the EU and the United States, as well as current bilateral initiatives, are further welcome steps. The staff would encourage the authorities to eliminate the price-band scheme that remains in place for a few agricultural goods.

50. Staff is encouraged by the open debate on policies to promote strong economic growth and further reduce poverty over the medium term. Enhancing education and labor flexibility are key to promoting strong and sustainable growth and reduce poverty. One of the main challenges will also be to ensure that the children of the poor have access to education, where there is room for improvement. Chile Solidario is a promising approach to deal with poverty in a comprehensive manner.

51. Chile's medium term outlook remains favorable. Public debt ratios are low, and the sustained implementation of the fiscal rule is consistent with a further decline in the public debt to GDP ratio over the medium term. While the external debt of the private sector is relatively high, it does not give rise to concern because it is at relatively long terms, and part of the debt is held as claims of parent companies on their Chilean affiliates.

52. Chile's data are of good quality, timely, and adequate for surveillance purposes. With the introduction of the 2004 budget, the authorities have removed most of the differences that existed with Fund standards. The authorities have sought technical assistance, so as to produce high quality data.

53. It is recommended that the next Article IV consultation with Chile be held on the standard 12-month cycle. 
Table 1. Chile: Selected Economic Indicators

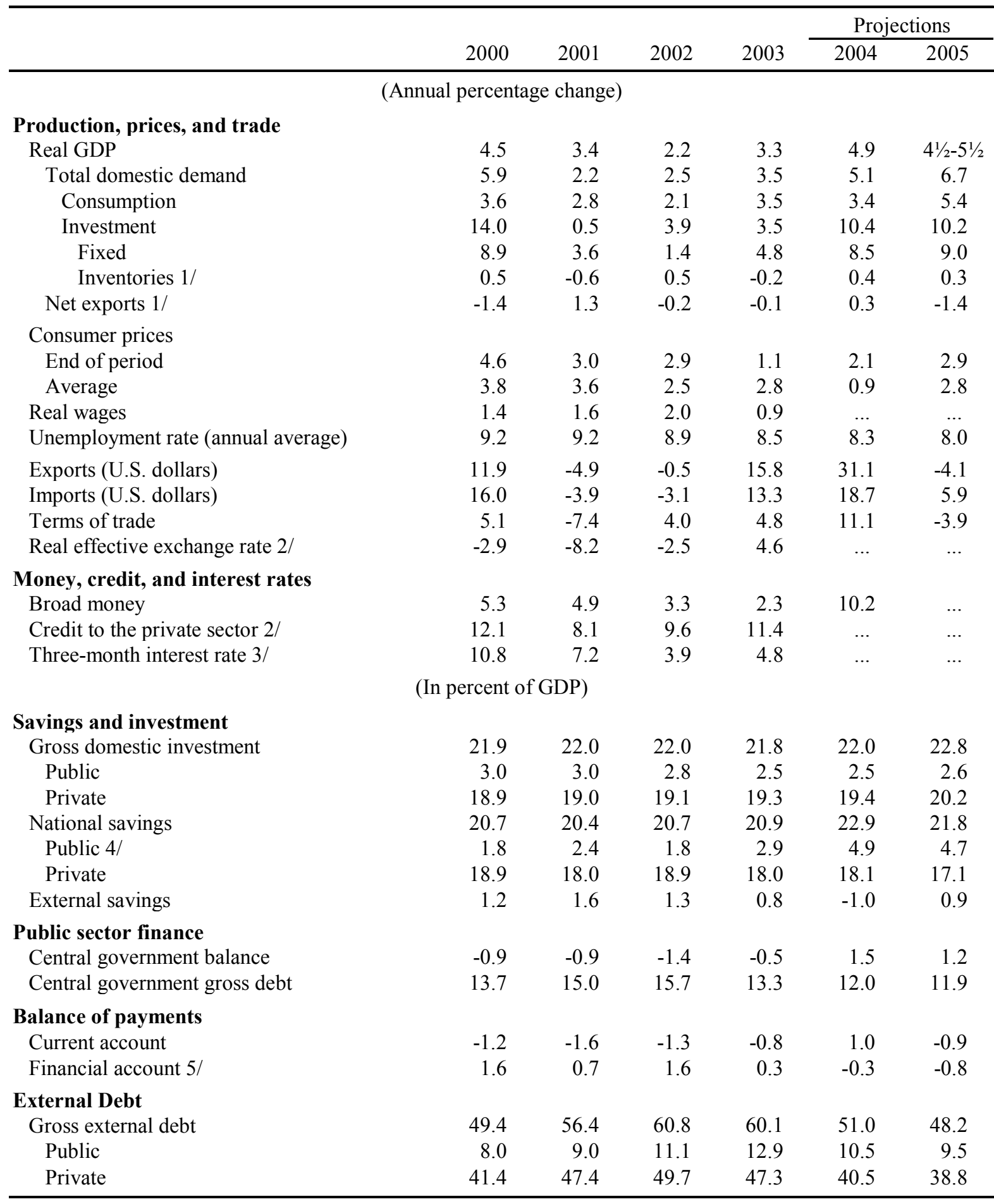

Sources: Central Bank of Chile, Ministry of Finance, Haver Analytics, and Fund staff estimates.

1/ Contribution to growth.

2/ End of period; authorities' definition of the real effective exchange rate. A decline indicates a depreciation of the peso.

3 / Nominal rates, in percent per annum, period average, on 90-day central bank promissory notes.

4/ Gross saving of the general government sector, including the deficit of the central bank.

$5 /$ Including errors and omissions, but excluding reserves. 
Table 2. Chile: Summary Operations of the Central Government (in percent of GDP)

\begin{tabular}{|c|c|c|c|c|c|c|}
\hline & \multirow[b]{2}{*}{2000} & \multirow[b]{2}{*}{2001} & \multirow[b]{2}{*}{2002} & \multirow[b]{2}{*}{2003} & \multicolumn{2}{|c|}{ Projections } \\
\hline & & & & & 2004 & 2005 \\
\hline \multicolumn{7}{|c|}{ I. Central Government Accounts } \\
\hline Overall balance $1 /$ & -0.9 & -0.9 & -1.4 & -0.5 & 1.5 & 1.2 \\
\hline Total revenue & 21.9 & 21.8 & 21.1 & 21.2 & 22.5 & 21.9 \\
\hline Taxes & 16.5 & 16.6 & 16.6 & 16.3 & 16.2 & 16.5 \\
\hline Income on assets & 0.7 & 0.7 & 0.6 & 0.6 & 0.4 & 0.4 \\
\hline Social contributions & 1.4 & 1.4 & 1.5 & 1.5 & 1.5 & 1.4 \\
\hline Grants & 0.2 & 0.3 & 0.2 & 0.2 & 0.1 & 0.1 \\
\hline Surplus of government operations & 1.8 & 1.4 & 1.3 & 1.7 & 3.7 & 2.9 \\
\hline Other & 1.2 & 1.4 & 0.9 & 1.0 & 0.7 & 0.5 \\
\hline Total expenditure & 22.8 & 22.7 & 22.4 & 21.7 & 21.0 & 20.7 \\
\hline Consumption & 5.9 & 5.9 & 5.9 & 5.8 & 5.5 & 5.3 \\
\hline Social benefits & 5.6 & 5.6 & 5.5 & 5.4 & 5.1 & 5.0 \\
\hline Subsidies and grants & 5.9 & 5.8 & 5.9 & 5.7 & 6.0 & 5.8 \\
\hline Interest payments & 1.7 & 1.6 & 1.2 & 1.2 & 0.8 & 1.2 \\
\hline Other & 0.2 & 0.2 & 0.2 & 0.2 & 0.1 & 0.1 \\
\hline Gross investment & 2.5 & 2.6 & 2.5 & 2.2 & 2.2 & 2.2 \\
\hline Defense & 0.3 & 0.3 & 0.3 & 0.2 & 0.2 & 0.2 \\
\hline Non-defense & 2.2 & 2.3 & 2.2 & 2.0 & 2.0 & 2.1 \\
\hline Net capital transfers & 1.0 & 1.1 & 1.2 & 1.3 & 1.3 & 1.1 \\
\hline \multicolumn{7}{|c|}{ II. Structural Balance } \\
\hline Structural balance & 0.3 & 1.0 & 0.7 & 0.7 & 0.8 & 0.9 \\
\hline Overall balance $2 /$ & -0.5 & -0.5 & -1.3 & -0.5 & 1.6 & 1.8 \\
\hline Revenue & 21.9 & 21.8 & 21.0 & 21.2 & 22.8 & 22.6 \\
\hline Expenditure & 22.3 & 22.3 & 22.3 & 21.7 & 21.2 & 20.9 \\
\hline \multicolumn{7}{|l|}{ Memorandum items: } \\
\hline Expenditure accounting differences & & & & & & \\
\hline Capitalized interest on $\mathrm{BCCh}$ debt & 0.4 & 0.3 & 0.0 & 0.0 & 0.0 & 0.1 \\
\hline UF valuation changes $3 /$ & 0.1 & 0.0 & 0.0 & 0.0 & 0.0 & 0.0 \\
\hline Copper transfers & 1.1 & 0.7 & 0.6 & 0.9 & 3.3 & 2.7 \\
\hline Military & 0.4 & 0.4 & 0.3 & 0.4 & 0.6 & 0.5 \\
\hline Non-military & 0.7 & 0.3 & 0.2 & 0.6 & 2.7 & 2.2 \\
\hline
\end{tabular}

Sources: Ministry of Finance (DIPRES) and staff estimates.

1/ Includes valuation adjustments (as income on assets; as interest expenditures on liabilities) to the stock of UF (inflation-indexed) debt and includes the accrued interest on debt held by the central bank. These adjustments bring the estimates in line with the Government Finance Statistics Manual (2001). Details are available as accounting differences (memorandum items).

2/ Calculated using the authorities' accounting methodology; this balance does not include the capitalized interest on BCCh debt and the valuation changes to the stock of UF debt. In 2004 and 2005, these estimates also reflect the authorities' economic assumptions. As a result, the revenue estimates differ, largely because the staff and the authorities have different copper price assumptions.

3/ The revenue effects of the UF valuation adjustments are small (less than 0.1 percent of GDP) and not shown. 


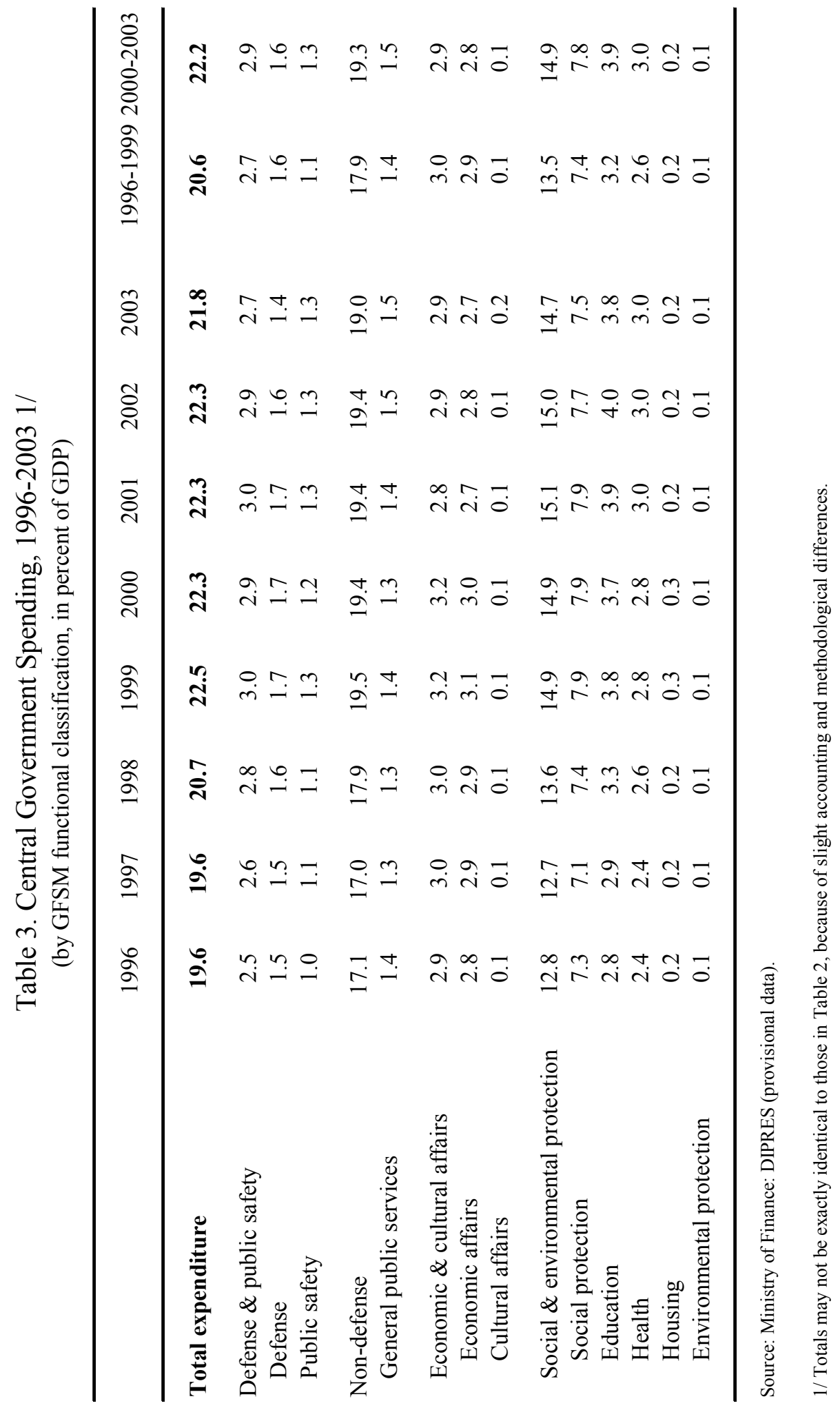


Table 4. Chile: Summary Operations of the Public Sector (in percent of GDP)

\begin{tabular}{|c|c|c|c|c|c|c|}
\hline & \multirow[b]{2}{*}{2000} & \multirow[b]{2}{*}{2001} & \multirow[b]{2}{*}{2002} & \multirow[b]{2}{*}{2003} & \multicolumn{2}{|c|}{ Projections } \\
\hline & & & & & 2004 & 2005 \\
\hline \multicolumn{7}{|c|}{ I. Central government } \\
\hline Balance & -0.9 & -0.9 & -1.4 & -0.5 & 1.5 & 1.2 \\
\hline Total revenue & 21.9 & 21.8 & 21.1 & 21.2 & 22.5 & 21.9 \\
\hline \multicolumn{7}{|l|}{ of which: } \\
\hline government enterprise receipts & 2.5 & 1.8 & 1.7 & 2.3 & 4.5 & 3.8 \\
\hline other intragovernmental receipts & 0.2 & 0.2 & 0.2 & 0.2 & 0.1 & 0.1 \\
\hline Total expenditures $1 /$ & 22.8 & 22.7 & 22.4 & 21.7 & 21.0 & 20.7 \\
\hline of which: intragovernmental transfers & 0.4 & 0.4 & 0.1 & 0.0 & 0.0 & 0.1 \\
\hline Current & 19.3 & 19.0 & 18.7 & 18.2 & 17.5 & 17.3 \\
\hline Capital & 3.5 & 3.7 & 3.7 & 3.5 & 3.5 & 3.4 \\
\hline \multicolumn{7}{|c|}{ II. Municipalities 2/ } \\
\hline Balance & 0.2 & 0.3 & 0.3 & 0.3 & 0.3 & 0.4 \\
\hline Total revenue & 2.3 & 2.2 & 2.2 & 2.2 & 2.1 & 2.1 \\
\hline of which: intragovernmental receipts & 0.0 & 0.0 & 0.0 & 0.0 & 0.0 & 0.0 \\
\hline Total expenditures & 2.1 & 2.0 & 2.0 & 1.9 & 1.8 & 1.7 \\
\hline of which: intragovernmental transfers & 0.2 & 0.2 & 0.2 & 0.2 & 0.1 & 0.1 \\
\hline Current & 1.6 & 1.6 & 1.6 & 1.6 & 1.4 & 1.4 \\
\hline Capital & 0.5 & 0.4 & 0.3 & 0.3 & 0.3 & 0.3 \\
\hline \multicolumn{7}{|c|}{ III. Central bank } \\
\hline Balance & -1.4 & -1.0 & -1.2 & -0.7 & -0.8 & -0.6 \\
\hline Net operating balance & -0.1 & 0.0 & -0.1 & 0.0 & 0.0 & 0.0 \\
\hline Net interest balance $1 /$ & -1.4 & -1.0 & -1.1 & -0.6 & -0.7 & -0.5 \\
\hline \multicolumn{7}{|c|}{ IV. State-owned enterprises (non-financial) } \\
\hline Balance & 0.3 & -0.4 & -0.6 & 0.3 & 0.2 & 0.3 \\
\hline Total revenue & 11.3 & 10.8 & 11.8 & 11.1 & 11.8 & 11.3 \\
\hline of which: intragovernmental receipts & 0.0 & 0.0 & 0.0 & 0.0 & 0.0 & 0.0 \\
\hline Total expenditures & 11.1 & 11.2 & 12.4 & 10.8 & 11.6 & 11.0 \\
\hline of which: intergovernmental transfers & 1.6 & 1.3 & 1.3 & 1.7 & 2.6 & 2.2 \\
\hline Current & 10.3 & 9.9 & 10.6 & 10.5 & 10.7 & 10.2 \\
\hline Capital & 0.7 & 1.3 & 1.9 & 0.3 & 0.9 & 0.8 \\
\hline
\end{tabular}

Sources: Ministry of Finance (DIPRES), Central Bank of Chile, and staff estimates.

$1 /$ Includes the effects of valuation changes (inflation) to the stock of UF debt and accrued interest on Treasury debt.

2/ On a cash basis. 
Table 5. Chile: Indicators of External Vulnerability

(in percent; unless otherwise indicated)

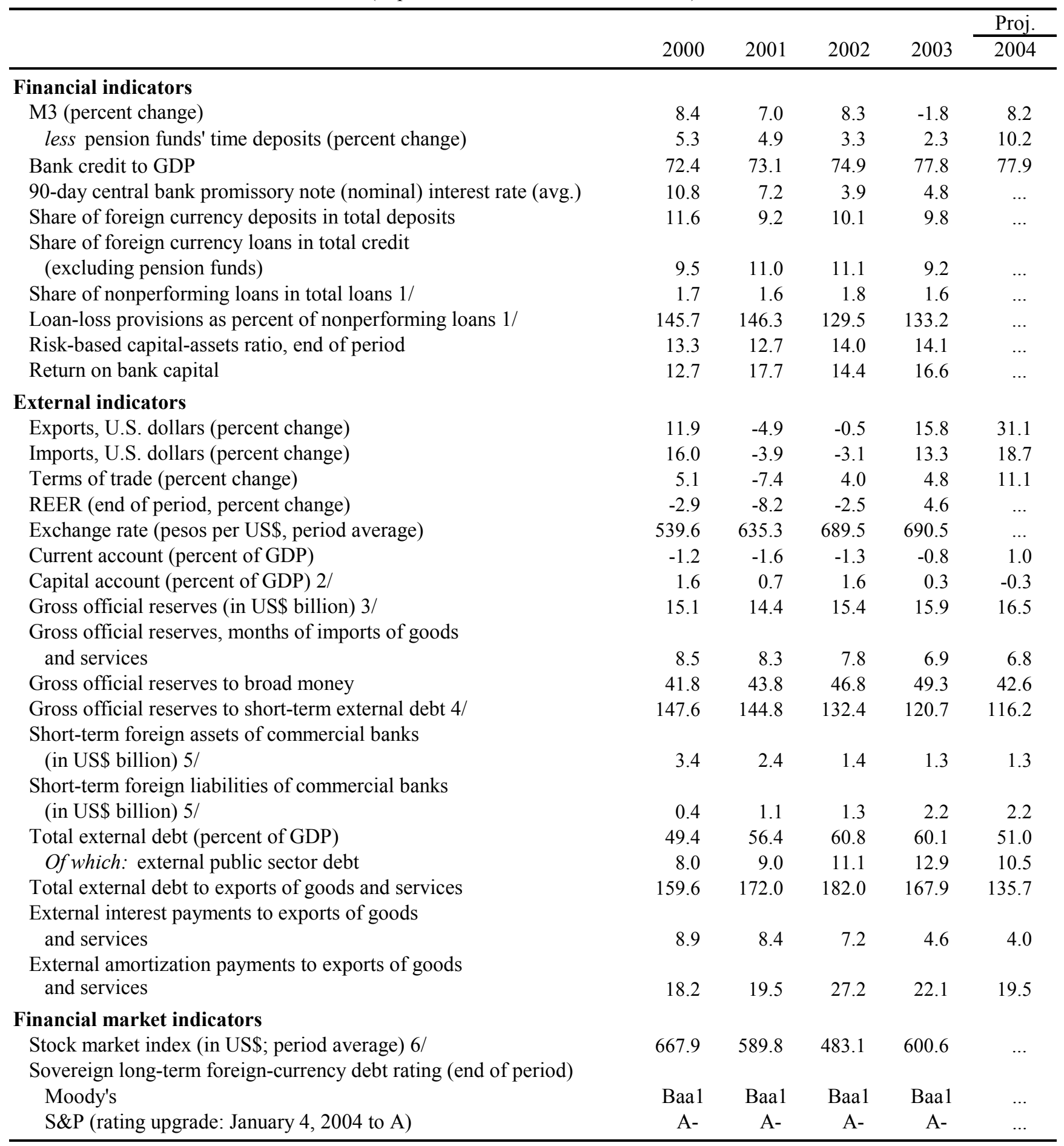

Sources: Central Bank of Chile, Haver Analytics, and Fund staff estimates.

1/ Official measure of non-performing loans.

2/ Includes errors and omissions.

3/ Gold valued at end-period market prices.

4/ As measured by the central bank; includes amortization of medium/long-term debt due during the following year, but not trade credits.

5/ Refers to the commercial banking sector including the Banco del Estado de Chile.

6/ Morgan-Stanley Capital International index (Dec/1987=100). 
Table 6. Chile: Balance of Payments-Medium-Term Projections

\begin{tabular}{|c|c|c|c|c|c|c|c|c|c|c|}
\hline & \multirow[b]{2}{*}{2000} & \multirow[b]{2}{*}{2001} & \multirow[b]{2}{*}{2002} & \multirow[b]{2}{*}{2003} & \multicolumn{6}{|c|}{ Projections } \\
\hline & & & & & 2004 & 2005 & 2006 & 2007 & 2008 & 2009 \\
\hline \multicolumn{11}{|c|}{ (In billions of U.S. dollars) } \\
\hline Current account & -0.9 & -1.1 & -0.9 & -0.6 & 0.9 & -0.8 & -1.8 & -2.5 & -2.9 & -3.4 \\
\hline Trade balance & 2.1 & 1.8 & 2.3 & 3.0 & 6.2 & 3.8 & 2.4 & 2.0 & 2.3 & 2.4 \\
\hline Exports & 19.2 & 18.3 & 18.2 & 21.0 & 27.6 & 26.5 & 25.9 & 26.6 & 28.4 & 30.1 \\
\hline Copper & 7.3 & 6.5 & 6.3 & 7.5 & 12.9 & 11.2 & 10.2 & 10.2 & 11.0 & 11.6 \\
\hline Non-copper & 11.9 & 11.7 & 11.9 & 13.5 & 14.7 & 15.2 & 15.7 & 16.4 & 17.4 & 18.5 \\
\hline Imports & -17.1 & -16.4 & -15.9 & -18.0 & -21.4 & -22.7 & -23.5 & -24.5 & -26.1 & -27.7 \\
\hline Financial services (net) & -2.9 & -2.5 & -2.9 & -3.3 & -5.1 & -4.1 & -3.8 & -4.0 & -4.8 & -5.4 \\
\hline Other services and transfers (net) & -0.2 & -0.4 & -0.2 & -0.3 & -0.3 & -0.5 & -0.4 & -0.4 & -0.5 & -0.4 \\
\hline Capital account $1 /$ & 1.2 & 0.5 & 1.1 & 0.2 & -0.2 & -0.7 & 2.2 & 3.3 & 3.8 & 4.3 \\
\hline Foreign investment (net) & 0.9 & 2.6 & 1.6 & 1.6 & 2.5 & 2.3 & 2.4 & 2.7 & 3.0 & 3.4 \\
\hline Assets & -4.0 & -1.6 & -0.3 & -1.4 & -1.3 & -1.3 & -1.4 & -1.4 & -1.5 & -1.6 \\
\hline Liabilities & 4.9 & 4.2 & 1.9 & 3.0 & 3.7 & 3.6 & 3.8 & 4.1 & 4.5 & 5.0 \\
\hline Other capital flows & 0.4 & -2.1 & -0.5 & -1.4 & -2.7 & -3.0 & -0.1 & 0.6 & 0.7 & 0.8 \\
\hline Medium- and long-term (net) & 0.0 & 0.0 & -0.7 & -0.8 & -0.5 & -1.2 & 1.7 & 2.5 & 2.7 & 2.9 \\
\hline Disbursements & 4.3 & 4.4 & 5.4 & 4.9 & 6.0 & 4.4 & 6.6 & 8.1 & 7.6 & 7.8 \\
\hline Amortizations & -4.2 & -4.4 & -6.1 & -5.7 & -6.4 & -5.7 & -4.9 & -5.6 & -4.8 & -4.9 \\
\hline Other capital (net) $1 /$ & 0.3 & -2.1 & 0.2 & -0.6 & -2.3 & -1.7 & -1.8 & -1.9 & -2.0 & -2.1 \\
\hline Overall balance & 0.3 & -0.6 & 0.2 & -0.4 & 0.7 & -1.5 & 0.4 & 0.8 & 0.9 & 0.9 \\
\hline Reserve assets (increase -) & -0.3 & 0.6 & -0.2 & 0.4 & -0.7 & 1.5 & -0.4 & -0.8 & -0.9 & -0.9 \\
\hline Valuation adjustment & -0.2 & -0.1 & 0.8 & 0.9 & 0.0 & 0.0 & 0.0 & 0.0 & 0.0 & 0.0 \\
\hline Chg. in official reserves (increase -) & -0.2 & 0.7 & -1.0 & -0.5 & -0.7 & 1.5 & -0.4 & -0.8 & -0.9 & -0.9 \\
\hline \multicolumn{11}{|c|}{ (In months of imports of goods and services) } \\
\hline Gross official international reserves $2 /$ & 8.5 & 8.3 & 7.8 & 6.9 & 6.8 & 6.0 & 5.9 & 5.9 & 5.8 & 5.8 \\
\hline \multicolumn{11}{|c|}{ (Annual change in percent) } \\
\hline Copper export prices $3 /$ & 14.8 & -14.0 & 0.4 & 12.9 & 51.7 & -14.8 & -13.0 & -5.0 & 2.6 & 1.3 \\
\hline Copper export volumes & 5.3 & 4.3 & -4.3 & 5.8 & 13.5 & 2.0 & 4.8 & 4.8 & 4.8 & 4.8 \\
\hline Non-copper export prices & 2.2 & -12.2 & -1.8 & 5.3 & 3.8 & -0.9 & -2.0 & -1.1 & 1.2 & 1.0 \\
\hline Non-copper export volume & 5.6 & 14.3 & 5.2 & 8.5 & 4.9 & 4.8 & 5.1 & 5.4 & 5.4 & 5.4 \\
\hline Total export prices & 6.7 & -12.1 & -0.9 & 8.0 & 20.4 & -7.4 & -6.7 & -2.7 & 1.6 & 1.0 \\
\hline Total export volume & 4.9 & 8.2 & 0.4 & 7.2 & 8.9 & 3.6 & 5.0 & 5.2 & 5.2 & 5.2 \\
\hline Total import price & 1.6 & -5.1 & -4.7 & 3.1 & 8.4 & -3.7 & -3.0 & -1.2 & 0.1 & 0.7 \\
\hline Total import volume & 13.9 & 1.6 & 1.4 & 9.5 & 9.9 & 9.9 & 7.0 & 5.6 & 6.1 & 5.6 \\
\hline Terms of trade & 5.1 & -7.4 & 4.0 & 4.8 & 11.1 & -3.9 & -3.7 & -1.5 & 1.5 & 0.2 \\
\hline Real GDP & 4.5 & 3.4 & 2.2 & 3.3 & 4.9 & 5.0 & 5.3 & 5.1 & 4.8 & 4.3 \\
\hline LIBOR (in percent) & 6.6 & 3.7 & 1.9 & 1.2 & 1.6 & 3.8 & 5.4 & 5.5 & 5.5 & 5.5 \\
\hline \multicolumn{11}{|c|}{ (In percent of GDP) } \\
\hline Gross domestic investment & 21.9 & 22.0 & 22.0 & 21.8 & 22.0 & 22.8 & 22.6 & 22.5 & 22.4 & 22.5 \\
\hline Public sector & 3.0 & 3.0 & 2.8 & 2.5 & 2.5 & 2.6 & 2.5 & 2.4 & 2.8 & 2.9 \\
\hline Private sector and inventory change & 18.9 & 19.0 & 19.1 & 19.3 & 19.4 & 20.2 & 20.2 & 20.1 & 19.7 & 19.6 \\
\hline External current account balance & -1.2 & -1.6 & -1.3 & -0.8 & 1.0 & -0.9 & -1.9 & -2.4 & -2.6 & -2.8 \\
\hline Gross national savings & 20.7 & 20.4 & 20.7 & 20.9 & 22.9 & 21.8 & 20.7 & 20.1 & 19.8 & 19.6 \\
\hline Public sector $4 /$ & 1.8 & 2.4 & 1.8 & 2.9 & 4.9 & 4.7 & 4.3 & 4.2 & 4.1 & 4.2 \\
\hline Private sector & 18.9 & 18.0 & 18.9 & 18.0 & 18.1 & 17.1 & 16.4 & 15.9 & 15.7 & 15.4 \\
\hline Total external debt (end of period) & 49.4 & 56.4 & 60.8 & 60.1 & 51.0 & 48.2 & 48.5 & 49.3 & 50.1 & 51.1 \\
\hline \multicolumn{11}{|l|}{ Memorandum items: } \\
\hline Copper price (LME; U.S. cents per pound) & 82.2 & 71.7 & 70.8 & 80.7 & 122.5 & 104.3 & 90.7 & 86.2 & 88.5 & 89.6 \\
\hline Copper exports (thousand metric tons) & 4,401 & 4,590 & 4,394 & 4,650 & 5,277 & 5,383 & 5,641 & 5,911 & 6,195 & 6,492 \\
\hline
\end{tabular}

Sources: Central Bank of Chile, Haver Analytics, and Fund staff estimates.

1 / Includes errors and omissions.

2/ Gold at market valuation. End-year stock of reserves in relation to imports of the following year.

3/ Chilean export price.

4/ Net of estimated losses of the central bank. 
Table 7. Chile: External Debt and Debt Service Projections

\begin{tabular}{|c|c|c|c|c|c|c|c|c|c|c|}
\hline & \multirow[b]{2}{*}{2000} & \multirow[b]{2}{*}{2001} & \multirow[b]{2}{*}{2002} & \multirow[b]{2}{*}{2003} & \multicolumn{6}{|c|}{ Projections } \\
\hline & & & & & 2004 & 2005 & 2006 & 2007 & 2008 & 2009 \\
\hline \multicolumn{11}{|c|}{ (In billions of U.S. dollars, end of period) } \\
\hline Total debt outstanding $1 /$ & 37.2 & 38.5 & 41.0 & 43.4 & 44.6 & 45.1 & 48.7 & 53.1 & 57.8 & 62.9 \\
\hline Of which: external private debt & 31.2 & 32.4 & 33.5 & 34.1 & 35.4 & 36.3 & 39.9 & 45.0 & 50.4 & 56.0 \\
\hline percent change & 8.3 & 4.0 & 3.3 & 1.9 & 3.9 & 2.4 & 10.1 & 12.7 & 12.0 & 11.1 \\
\hline Public sector & 5.0 & 5.3 & 6.5 & 7.9 & 8.0 & 7.5 & 7.5 & 6.8 & 6.1 & 5.6 \\
\hline Of which: central government & 2.5 & 3.0 & 3.6 & 4.6 & 4.7 & 4.3 & 4.2 & 3.5 & 2.9 & 2.3 \\
\hline Private sector & 26.0 & 27.9 & 28.6 & 28.0 & 28.8 & 29.6 & 33.0 & 37.9 & 43.1 & 48.5 \\
\hline Financial sector & 1.3 & 1.5 & 2.6 & 3.1 & 3.1 & 3.1 & 3.1 & 3.1 & 3.1 & 3.1 \\
\hline Non-financial sector & 24.8 & 26.4 & 26.0 & 24.9 & 25.8 & 26.5 & 29.9 & 34.8 & 40.0 & 45.4 \\
\hline Interest & 2.1 & 1.9 & 1.6 & 1.2 & 1.3 & 2.0 & 2.5 & 2.7 & 3.1 & 3.6 \\
\hline \multicolumn{11}{|c|}{ (In percent of GDP) } \\
\hline Total external debt, end-period $1 /$ & 49.4 & 56.4 & 60.8 & 60.1 & 51.0 & 48.2 & 48.5 & 49.3 & 50.1 & 51.1 \\
\hline Gross change (in percent) & 3.8 & 14.0 & 8.0 & -1.2 & -15.3 & -5.4 & 0.5 & 1.6 & 1.7 & 2.0 \\
\hline Gross change of nominal stock (in percent) & 7.0 & 3.7 & 6.3 & 5.9 & 2.8 & 1.2 & 7.8 & 9.1 & 8.9 & 8.7 \\
\hline Of which: external private debt & 41.4 & 47.4 & 49.7 & 47.3 & 40.5 & 38.8 & 39.8 & 41.8 & 43.7 & 45.6 \\
\hline Of which: external public debt & 8.0 & 9.0 & 11.1 & 12.9 & 10.5 & 9.5 & 8.7 & 7.5 & 6.4 & 5.6 \\
\hline Interest payments on external debt & 2.8 & 2.8 & 2.4 & 1.7 & 1.5 & 2.1 & 2.4 & 2.5 & 2.7 & 2.9 \\
\hline \multicolumn{11}{|c|}{ (In percent of exports of goods and services) } \\
\hline \multicolumn{11}{|c|}{ (In percent of GDP) } \\
\hline Net international reserves & 20.1 & 21.1 & 22.8 & 22.0 & 18.8 & 16.1 & 15.4 & 15.1 & 14.9 & 14.7 \\
\hline Net financial services payments & 3.8 & 3.7 & 4.3 & 4.5 & 5.8 & 4.4 & 3.8 & 3.8 & 4.1 & 4.4 \\
\hline GDP (billions of U.S. \$) 2/ & 75.2 & 68.4 & 67.3 & 72.1 & 87.5 & 93.6 & 100.4 & 107.8 & 115.4 & 123.0 \\
\hline percent change & 3.1 & -9.1 & -1.6 & 7.2 & 21.4 & 6.9 & 7.2 & 7.3 & 7.1 & 6.6 \\
\hline
\end{tabular}

Sources: Central Bank of Chile, Haver Analytics, and Fund staff estimates.

1/ Original maturity basis; end of period basis.

2/ At current prices and exchange rates. 
Table 8. Chile: Financial System Structure, 2000-2003

(Assets as percent of GDP, as of December of each year)

\begin{tabular}{|c|c|c|c|c|c|c|c|c|}
\hline & \multicolumn{2}{|c|}{2000} & \multicolumn{2}{|c|}{2001} & \multicolumn{2}{|c|}{2002} & \multicolumn{2}{|c|}{2003} \\
\hline & Number & Assets & Number & Assets & Number & Assets & Number & Assets \\
\hline Total Financial System & 448 & 188.9 & 467 & 192.3 & 483 & 197.0 & 417 & 201.4 \\
\hline Banking System & 29 & 97.7 & 28 & 99.6 & 26 & 98.4 & 26 & 95.6 \\
\hline Banks & 28 & 96.8 & 27 & 99.0 & 25 & 98.0 & 26 & 95.6 \\
\hline Private & 27 & 83.7 & 26 & 85.9 & 24 & 83.5 & 25 & 80.8 \\
\hline Domestic & 9 & 38.5 & 9 & 39.5 & 10 & 39.6 & 12 & 41.8 \\
\hline Foreign & 18 & 45.1 & 17 & 46.4 & 14 & 43.9 & 13 & 39.0 \\
\hline State-owned & 1 & 13.2 & 1 & 13.2 & 1 & 14.4 & 1 & 14.8 \\
\hline Finance Companies & 1 & 0.9 & 1 & 0.6 & 1 & 0.4 & 0 & 0.0 \\
\hline Institutional investors & 262 & 76.6 & 281 & 81.7 & 303 & 87.4 & 312 & 93.1 \\
\hline Insurance companies & 56 & 16.5 & 54 & 17.9 & 55 & 19.1 & 55 & 20.2 \\
\hline Life and Retirement & 33 & 16.0 & 32 & 17.5 & 32 & 18.7 & 32 & 19.8 \\
\hline Non-life & 23 & 0.4 & 22 & 0.4 & 23 & 0.5 & 23 & 0.5 \\
\hline Pension funds & 8 & 51.0 & 7 & 53.6 & 7 & 55.8 & 7 & 59.7 \\
\hline Foreign-owned & 3 & 28.4 & 3 & 29.9 & 3 & 30.8 & 4 & 34.8 \\
\hline Domestically owned & 5 & 22.6 & 4 & 23.7 & 4 & 24.9 & 3 & 24.9 \\
\hline Mutual funds & 150 & 6.4 & 177 & 7.3 & 199 & 9.9 & 206 & 10.1 \\
\hline Investment funds & 29 & 1.9 & 30 & 2.0 & 31 & 2.0 & 35 & 2.2 \\
\hline Foreign capital investment funds & 18 & 0.9 & 13 & 0.9 & 11 & 0.7 & 9 & 0.9 \\
\hline Foreign venture capital funds & 1 & 0.0 & & 0.0 & & 0.0 & & 0.0 \\
\hline Other non-bank & 157 & 14.6 & 158 & 11.0 & 154 & 11.2 & 79 & 12.6 \\
\hline
\end{tabular}

Sources: Central Bank of Chile, Superintendency of Banks (SBIF), Superintendency of Insurance (SVS) 
Table 9. Millennium Development Goals

\begin{tabular}{|c|c|c|c|c|c|c|}
\hline & 1990 & 1995 & 2001 & 2002 & 2003 & $\begin{array}{c}2015 \\
\text { Target }\end{array}$ \\
\hline \multicolumn{7}{|l|}{ Goal 1: Eradicate extreme poverty and hunger } \\
\hline Poverty gap at $\$ 1$ a day (in percent of total population,) & $\ldots$ & $\ldots$ & 0.5 & $\ldots$ & $\ldots$ & $\ldots$ \\
\hline Percent of income or consumption held by poorest 20 percent & $\ldots$ & $\ldots$ & 3.3 & $\ldots$ & $\ldots$ & $\ldots$ \\
\hline Prevalence of child malnutrition (in percent of children under 5) & $\ldots$ & 0.9 & 0.8 & 0.8 & 0.5 & 0.5 \\
\hline \multicolumn{7}{|l|}{ Goal 2: Achieve universal primary education } \\
\hline Net primary enrollment ratio (in percent of relevant age group) & 87.7 & 87.3 & 88.8 & $\ldots$ & $\ldots$ & 100.0 \\
\hline Percentage of cohort reaching grade 5 (in percent) & $\ldots$ & 100.0 & 101.2 & $\ldots$ & $\ldots$ & 100.0 \\
\hline Youth literacy rate (in percent of ages $15-24$ ) & 98.1 & 98.5 & 98.9 & 99.0 & $\ldots$ & 100.0 \\
\hline Proportion of seats held by women in national parliament (in percent) & $\ldots$ & 8.0 & $\ldots$ & 10.1 & 10.1 & $\ldots$ \\
\hline \multicolumn{7}{|l|}{ Goal 4: Reduce child mortality } \\
\hline Under 5 mortality rate (per 1,000$)$ & 19.0 & 14.0 & 12.0 & 12.0 & $\ldots$ & 12.7 \\
\hline Infant mortality rate (per 1,000 live births) & 18.0 & 12.0 & 10.0 & 10.0 & $\ldots$ & $\ldots$ \\
\hline Immunization, measles (in percent of children under 12 months) & 82.0 & 97.0 & 99.0 & 95.0 & $\ldots$ & $\ldots$ \\
\hline \multicolumn{7}{|l|}{ Goal 5: Improve maternal health } \\
\hline Maternal mortality ratio (modeled estimate, per 100,000 live births) & $\ldots$ & $\ldots$ & 31.0 & 17.0 & $\ldots$ & 23.3 \\
\hline Births attended by skilled health staff (in percent of total) & $\ldots$ & 99.5 & 99.8 & 99.8 & $\ldots$ & $\ldots$ \\
\hline \multicolumn{7}{|l|}{ Goal 7: Ensure environmental sustainability } \\
\hline Forest area (in percent of total land area) & 21.0 & $\ldots$ & 20.7 & $\ldots$ & $\ldots$ & $\ldots$ \\
\hline Nationally protected areas (in percent of total land area) & $\ldots$ & 18.9 & 18.9 & 18.9 & 18.7 & $\ldots$ \\
\hline GDP per unit of energy use (PPP \$ per kg oil equivalent) & 4.5 & 5.7 & 6.2 & $\ldots$ & $\ldots$ & $\ldots$ \\
\hline $\mathrm{CO} 2$ emissions (metric tons per capita) & 2.7 & 3.1 & 3.9 & $\ldots$ & $\ldots$ & $\ldots$ \\
\hline Access to an improved water source (in percent of total population) & 90.0 & $\ldots$ & 93.0 & $\ldots$ & $\ldots$ & 95.0 \\
\hline Access to improved sanitation (in percent of total population) & 97.0 & $\ldots$ & 96.0 & $\ldots$ & $\ldots$ & $\ldots$ \\
\hline Access to secure tenure (in percent of total population) & $\ldots$ & $\ldots$ & $\ldots$ & $\ldots$ & $\ldots$ & $\ldots$ \\
\hline \multicolumn{7}{|l|}{ Goal 8: Develop a Global Partnership for Development } \\
\hline Youth unemployment rate (in percent of labor force ages 15-24) & 13.1 & 11.5 & 18.8 & 21.6 & 21.1 & $\ldots$ \\
\hline Fixed line and mobile telephones (per 1,000 people) & 67.0 & 141.2 & 568.1 & 658.6 & 658.6 & $\ldots$ \\
\hline Personal computers (per 1,000 people) & 9.4 & 33.2 & 106.5 & 119.3 & 119.3 & $\ldots$ \\
\hline
\end{tabular}

Sources: World Bank Development Indicators database, April 2004; authorities' estimates for 2003. 


\section{Chile-Fund Relations}

(As of May 31, 2004)

I. Membership Status: Joined 12/31/45; Article VIII.

II. General Resources Account

Quota

Fund holdings of Chilean pesos

Reserve tranche position

III. SDR Department

Net cumulative allocation

Holdings
SDR Million

856.10

562.85

293.25

SDR Million

121.92

32.46
Percent Quota

100.00

65.75

34.25

Percent Allocation

100.00

26.63

IV. Outstanding Purchases and Loans: None

V. Financial Arrangements:

$\begin{array}{cc}\text { Approval } & \text { Expiration } \\ \text { Date } & \text { Date }\end{array}$

Type of Arrangement

SBA

EFF

$\begin{array}{rr}11 / 08 / 89 & 11 / 07 / 90 \\ 8 / 15 / 85 & 8 / 14 / 89\end{array}$

\section{Amount Approved (SDR Million) (SDR Million) \\ Amount \\ Drawn}

650.00

VI. Projected Obligations to Fund (SDR Million; based on existing use of resources and present holdings of SDRs): None

VII. Exchange Arrangements: The exchange rate is permitted to float freely. On May 31, the interbank exchange rate was Ch\$632.32 per U.S. dollar. Chile's exchange system is currently free of restrictions on the making of payments and transfers for current international transactions.

VIII. Article IV Consultation: The Executive Board concluded the 2003 Article IV consultation on August 18, 2003. The staff report was subsequently released as Country Report No. 03/303.

IX. Technical Assistance: In June 1998, an FAD mission advised on the desirability of moving to a system of accrual accounting and budgeting. In June 1999, a joint FAD-STA mission advised on public expenditure management, the implementation of accrual based accounting, and government finance statistical systems. In May 2000, a mission from STA advised on money and banking statistics. In March 2001, a mission from STA assessed the quality of national account statistics. In March-April 2001, a mission from STA assessed Chile's data quality and dissemination practices against the IMF's SDDS. In April-May 2001, a mission from FAD advised on VAT administration issues, and a mission from STA advised on money and banking statistics (follow-up from May 2000 mission). In July 2001 an FAD mission advised on customs administration issues. In October 2002, a mission from MAE and WHD advised on nominalization and interest rate pass-through. In January 2003, a joint FAD/STA mission advised on fiscal statistics. In late 2003 and early 2004, an FSAP mission (joint Fund-Bank) assessed the Chilean financial system. 


\section{Chile-Financial Relations with the World Bank}

The most recent Country Assistance Strategy (CAS) for Chile, covering Fiscal Years 2002-05, was discussed by the Executive Board of the Bank in February 2002. The CAS calls for selectively focusing on areas in which the Bank has accumulated substantial knowledge and where the Government feels that the Bank can be instrumental in ensuring the successful implementation of its initiatives. To that aim, the strategy proposes to diversify the forms of financial assistance by providing for direct financing through regular investment and policy-based lending as well as for contingent financing.

The CAS also reflects efforts by the current administration to address persistent social challenges through improvements in the social safety net and human capital. Support in the area of social protection is being provided under the recently approved Social Protection Adjustment Loan DDO (FY04) and the accompanying TA loan, which aims at increasing access to social protection and social services for the neediest households. This loan is also expected to support Chile Solidario. Support in the area of human capital development has been provided through the Science for the Knowledge Economy Project (FY03), which fosters the developments of an effective innovation system and aims at improving the stock of human capital in the Chilean science and technology sector.

The IFC provides support for private infrastructure, small and medium enterprises, specialized financing in housing, and for the social sector. The IFC considers that Chile is a country from which experience can be learned for other countries, both within and outside the Latin America region. In addition, the IFC provides support to Chilean companies in their efforts to grow abroad. MIGA's support is expected to facilitate foreign direct investment in Chile.

There are currently six investment loans in Chile's operations portfolio, totaling US\$290.5 million in commitments (Table). Two of these loans, in support of the Second Municipal Development Project (FY99) and the Higher Education Project (FY99), had already been approved when the present CAS was discussed. The remaining four loans, in support of Public Expenditure Management (FY02), Lifelong Learning (FY02), Science for the Knowledge Economy (FY03), and the Social Protection TA Loan (FY04) are covered by the current CAS. A Social Protection Adjustment Loan DDO in the amount of US\$200 million, also approved in FY04, has been fully disbursed. Additional lending in FY2005-06 is expected to be in support of urban transport, other rural infrastructure services, and municipal development. 
Chile: Financial Relations with the World Bank

(In millions of U.S. dollars)

Commitments
(Net of
Cancellations) Disbursements $\quad$ Undisbursed

I. IBRD Operations (as of June 15, 2004)

Fully disbursed loans

Loans in process of disbursement

Agriculture

Education

Environment

Health

Municipal and urban

Public sector management

Transport

Water supply

Total loans

Repaid 1/

Outstanding

$\begin{array}{rrr}\mathbf{3 2 0 8 . 6} & \mathbf{3 2 0 8 . 6} & \mathbf{0 . 0} \\ \mathbf{2 9 0 . 5} & \mathbf{1 1 5 . 8} & \mathbf{1 7 4 . 5} \\ 0.0 & 0.0 & 0.0 \\ 246.5 & 100.2 & 146.2 \\ 0.0 & 0.0 & 0.0 \\ 0.0 & 0.0 & 0.0 \\ 10.1 & 8.3 & 1.6 \\ 23.2 & 7.2 & 16.0 \\ 0.0 & 0.0 & 0.0 \\ 0.0 & 0.0 & 0.0 \\ \mathbf{3 4 9 9 . 1} & \mathbf{3 . 3 2 4 . 4} & \mathbf{1 7 4 . 5} \\ \mathbf{2 9 2 2 . 5} & & \\ \mathbf{5 7 6 . 6} & & \end{array}$

II. IFC Operations (as of May 31, 2004) $\mathbf{0}$

4.5

46.2

0.0

1.6

6.0

0.0

174.5

IFC

\begin{tabular}{lrrrr}
\hline & Loans & Equity & Quasi Equity & Participation \\
\hline Held & 113.0 & 48.6 & 76.3 & 98.0 \\
Disbursed & 67.3 & 38.6 & 72.5 & 77.8
\end{tabular}

III. IBRD Loan Transactions (calendar year)

\begin{tabular}{lrrrr}
\hline & \multicolumn{5}{c}{ Actuals } \\
\hline Disbursements & 2001 & 2002 & 2003 & $20042 /$ \\
Repayments & 38.6 & 29.7 & 37.5 & 207.4 \\
Net lending & 118.5 & 202.3 & 172.7 & 221.6 \\
& -79.9 & -172.6 & -135.2 & -14.2 \\
\hline
\end{tabular}

Source: World Bank.

1/ Includes repayment from third parties.

2/ As of May 31, 2004. 


\section{Chile_-Statistical Issues}

\section{Monetary and real sectors}

The central bank publishes comprehensive statistics on the real and monetary sectors on a bi-weekly basis. STA is providing assistance to improve the quarterly national accounts, and has recently helped improve the classification and expand the institutional coverage of the monetary accounts. The new monetary statistics were published starting with the July 2003 issue of International Financial Statistics; revised time series based on the new methodology are now available to December 1997.

\section{Government finances and debt}

The Ministry of Finance publishes data on the central government and a summary of the accounts of the nonfinancial public sector. Beginning in 2003, central government operations data are published on a monthly basis, while data on the municipalities and public enterprises are presented on an annual basis, with a lag.

In the past, there were large differences between Chile's budget presentation and international standards. Chile had two large inconsistencies with international standards which, if corrected, would have led to an increase in the deficit of around $1 / 2$ percent of GDP:

- Off-budget transactions including: (i) military revenue and expenditures under Law 13.196, which dedicates 10 percent of the revenue from CODELCO's sales to the military; (ii) subsidies to the private sector through the Petroleum Stabilization Fund; and (iii) transactions involving the Copper Stabilization Fund that should have been recorded as net financing (and not income).

- $\quad$ The budget was strictly on a cash basis, leading to a significant understatement of expenditures when the government delayed payments on bonds held by the central bank - something it often did. Most of the bonds yield LIBOR plus 50 basis points, and the Treasury has the option of capitalizing all interest above 2 percent. This capitalized interest should be recognized as an interest expense.

With the introduction of the 2004 budget, the authorities rectified the most significant discrepancies and published a detailed list of their changes. Most importantly, the offbudget transactions were displayed and included in the budget. In addition, the authorities introduced accrual accounting for most transactions. This change means that the budget now records copper income on an accrual basis, and the Copper Stabilization Fund operates as a financing vehicle to help meet the accrued copper income. Finally, the authorities made progress in presenting the budget data in categories used by Government Financial Statistics Manual (GFSM 2001). 


\section{Additional improvements to the fiscal statistics are anticipated during 2004.}

- $\quad$ The central government will begin recording transactions in an integrated financial management system (SIGFE) that will allow real-time reports of fiscal transactions, on an accrual basis.

- $\quad$ Expenditure data will be presented according to GFSM 2001 classifications.

- $\quad$ Quarterly data back to 1987 will be made available, along with detailed balance sheet data-including, for the first time, an estimate of consumption of fixed capital.

- The authorities agreed to publish information on the effects of inflation on the value of inflation-indexed bonds in the forthcoming FY2005 budget.

Only two differences remain between the authorities' expenditure data and the methodology suggested by the GFSM 2001.

- Interest payments on Treasury debt held by the central bank is still recorded on a cash basis. As a result, interest recorded in the budget can be lower than the actual interest due (which should be on an accrual basis), because part of the interest payment on the debt held by the central bank is deferred.

- $\quad$ The authorities plan to only publish, but not include as an interest expense, the valuation changes due to inflation on indexed bonds in the budget.

As Table 2 indicates, these differences are not expected to be large in 2004. Into the mediumterm, these two differences would increase expenditure by only $1 / 4^{-1 / 2}$ percent of GDP.

\section{Balance of payments and external debt}

The central bank compiles balance of payments statistics on a quarterly basis, and publishes comprehensive statistics on the external sector on a bi-weekly basis. The process of reconciliation of data on short-term debt data with the BIS has been completed. Beginning in 2002, the central bank publishes the International Investment Position consistent with the balance of payments statement.

The coverage of the military sector in the external statistics is still not complete. In particular, the accuracy of data on military imports is unclear, as those imports that do not pass through customs are estimated by the central bank. Also, if the military receives external credits, information on this may not be available to the central bank; therefore, such financing may not appear in the balance of payments or external debt statistics. 


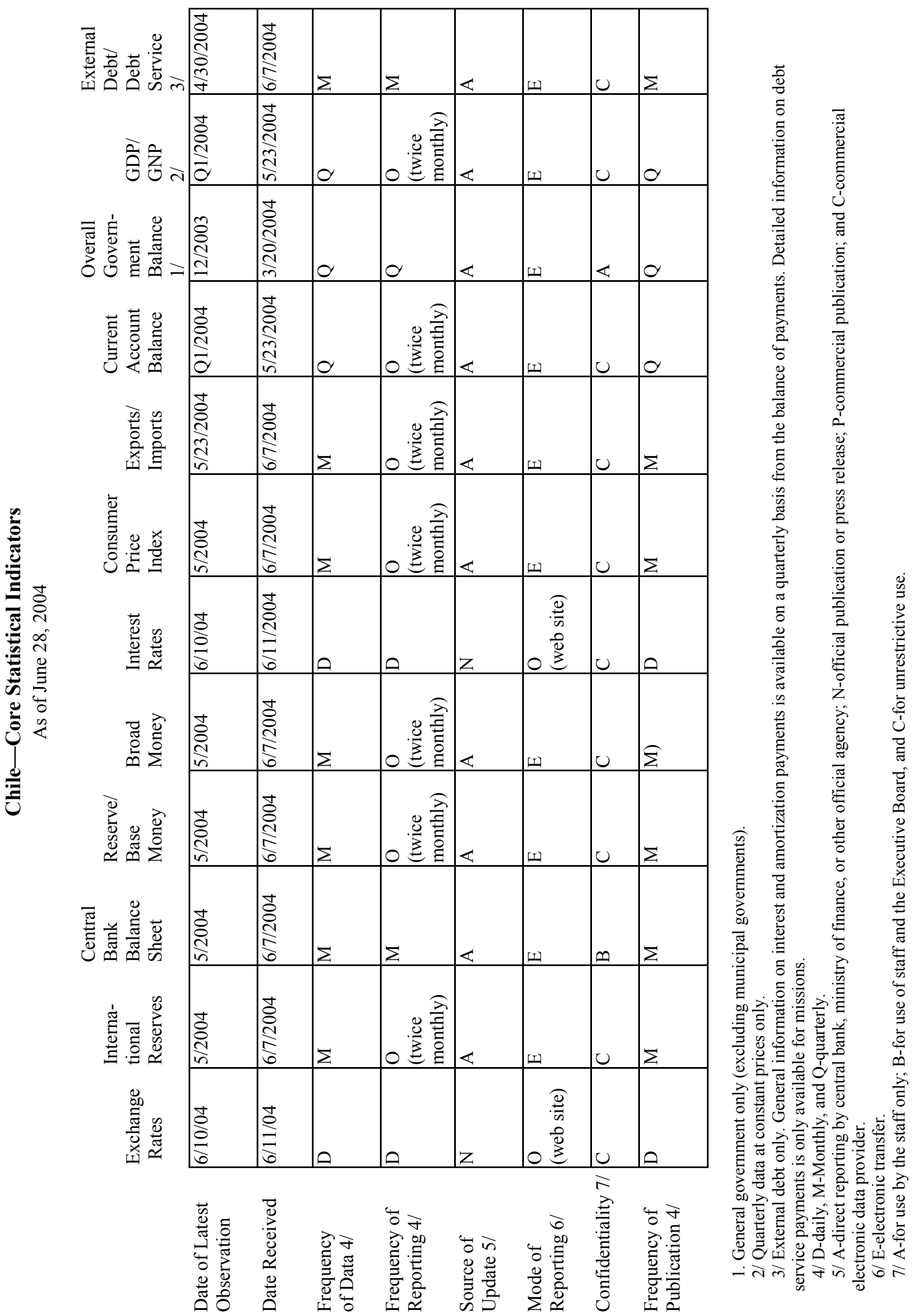




\section{Chile_-Debt Sustainability Analysis (DSA)}

1. This appendix assesses Chile's debt sustainability. The fiscal sustainability analysis focuses on the net debt of the non-financial public sector, because the central government holds a large stock of assets. ${ }^{1}$ In contrast, the external sustainability focuses on the gross debt position of the economy.

2. Under the baseline scenario for the public sector, over the medium term fiscal prudence as embedded in the structural balance rule would lead to a further decline in the-already low-net debt-to-GDP ratio. The primary balance would remain in surplus over the forecast horizon, well above 2 percent of GDP (Table 1), and net debt would decline from $12 \frac{1}{2}$ percent of GDP in 2004 to $10^{3} / 4$ percent by 2009 .

Computations made at the time of the 2004 budget suggest that the stock of net (central) government debt would be eliminated between 2012 and 2030. In most of the bounds tests, which assume significant shocks, the debt stock would not decline. However, the debt-to-GDP ratio would remain low by international standards and, in most cases, would

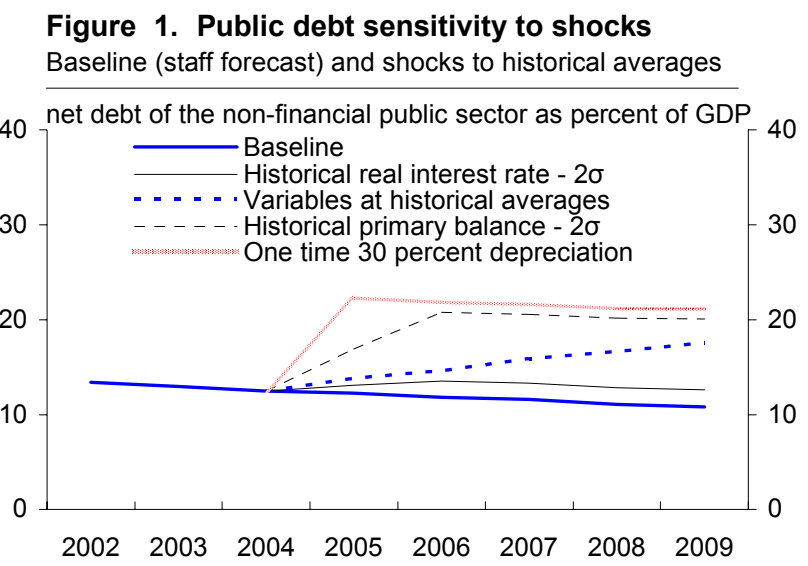
stabilize at or below 20 percent (Figure 1).

3. In the baseline scenario, external debt would remain well-contained over the medium term (Table 2). The relatively high gross external debt to GDP ratio reflects high borrowing abroad by the corporate sector (at end-2003, external public debt was equivalent to only $9 \frac{1}{4}$ percent of GDP). The ratio of gross external debt to GDP has improved sharply in recent years, due to the appreciation of the Chilean peso. The external debt of the private sector is relatively high, but there are mitigating factors to external vulnerability, including the presence of natural hedges for the export sector and access to financial hedges. Shortterm debt on a residual maturity basis represents only 22 percent of private sector external debt, and the average duration of medium-term debt is above five years. More than half of

\footnotetext{
${ }^{1}$ A net debt concept is used in the fiscal sustainability analysis because the central government holds a large stock of assets ( 7 percent of GDP at end-2003). Three categories of debt are not included in the assessment. First, a large stock of debt is in the form of recognition bonds (16 percent of GDP by end-2003), which represent the transition costs from the old pay-as-you-go public pension system to the private pension fund system. The amortization of this debt is not available in the Public Debt Report, so the decline in the debt may be somewhat overstated in the DSA. Second, the central bank debt stock is large (around 30 percent of GDP by end-2003), but offset by assets (mainly foreign reserves and Treasury debt), so that its net debt is low ( $1 / 2$ percent of GDP by end-2003). Finally, the central government has contingent liabilities on investment guarantees undertaken by public and private enterprises (around 10 percent of GDP).
} 
private external debt is owed by foreign-owned firms, with one third of this debt representing the claims of parent companies. Over the medium term, the debt ratio is projected to remain broadly stable, at around 50 percent of GDP.

\section{Chile's external debt is sensitive} to shocks. Although shocks to real GDP growth or the current account would have a limited impact, external price shocks would have a stronger impact on the debt ratio (Figure 2). In particular, the stock of debt is sensitive to exchange rate shocks; indeed, the share of external debt rose to above 60 percent of GDP in 2002 because of the sharp depreciation in the exchange rate. Nevertheless, Chile's aggregate net international investment position is strong, mitigating some of these concerns (Table, inset).

\section{Reflecting large foreign direct} investment, Chile's net international investment position is negative, but both the public and the financial sector have positive net positions. The assets abroad of the financial system largely reflect the holdings of pension funds and, to a lesser extent, banks abroad. The negative net position of the private sector ( 55 percent of GDP) largely reflects foreign direct investment. While the private nonfinancial sector holds debt abroad in the equivalent of 38 percent of GDP, most of it is medium and long-term (close to 5 years) and it is offset in part by holdings of assets equivalent to close to 20 percent (predominantly short-term).
Figure 2. Gross external debt sensitivity

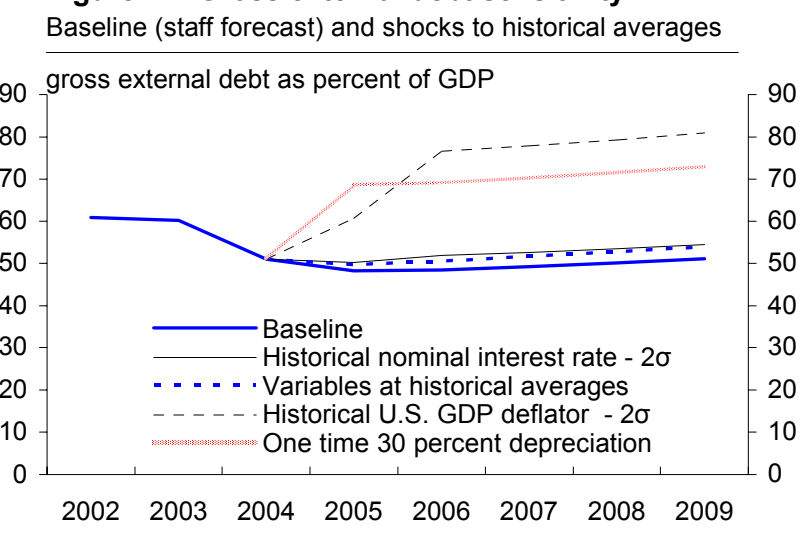

Table. International Investment Position, 2002 (stocks at end-year, in percent of GDP)

\begin{tabular}{lccc}
\hline & Assets & Liabilities & Net position \\
\hline Public sector & $\mathbf{2 4}$ & $\mathbf{1 1}$ & $\mathbf{1 3}$ \\
$\quad$ Reserves & 23 & & \\
Private sector & $\mathbf{6 0}$ & $\mathbf{1 1 4}$ & $\mathbf{- 5 5}$ \\
$\quad$ Financial & 12 & 7 & 6 \\
Non-financial & 47 & 108 & -60 \\
FDI & 19 & 66 & -47 \\
Equity & 0 & 3 & -3 \\
Debt & 20 & 38 & -19 \\
$\quad$ Commercial & 11 & 7 & 4 \\
$\quad$ Short-term & 7 & 1 & 7 \\
$\quad$ Medium/long-tern & 1 & 30 & -29 \\
\hline
\end{tabular}

Source: Central Bank of Chile.

\section{0

0

.




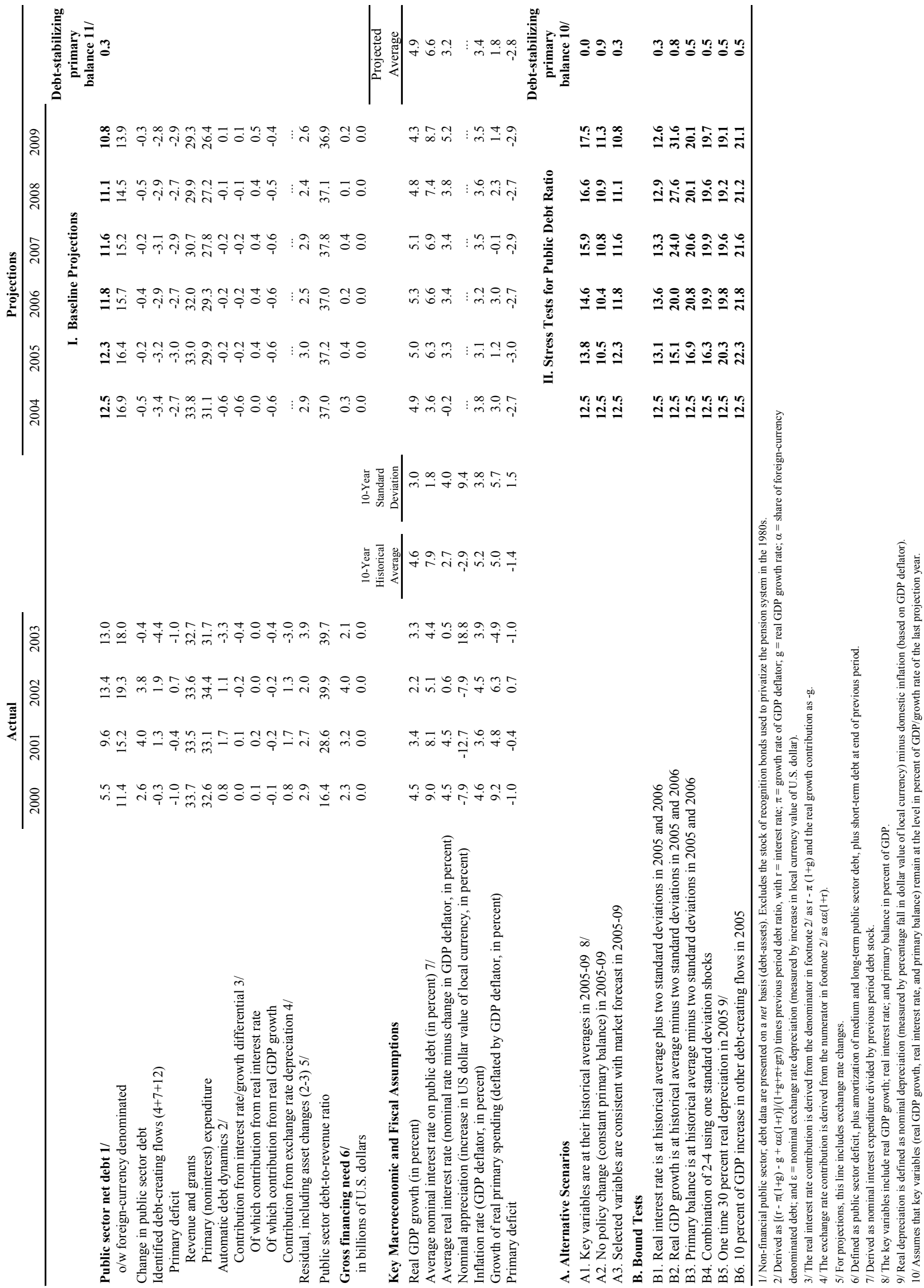




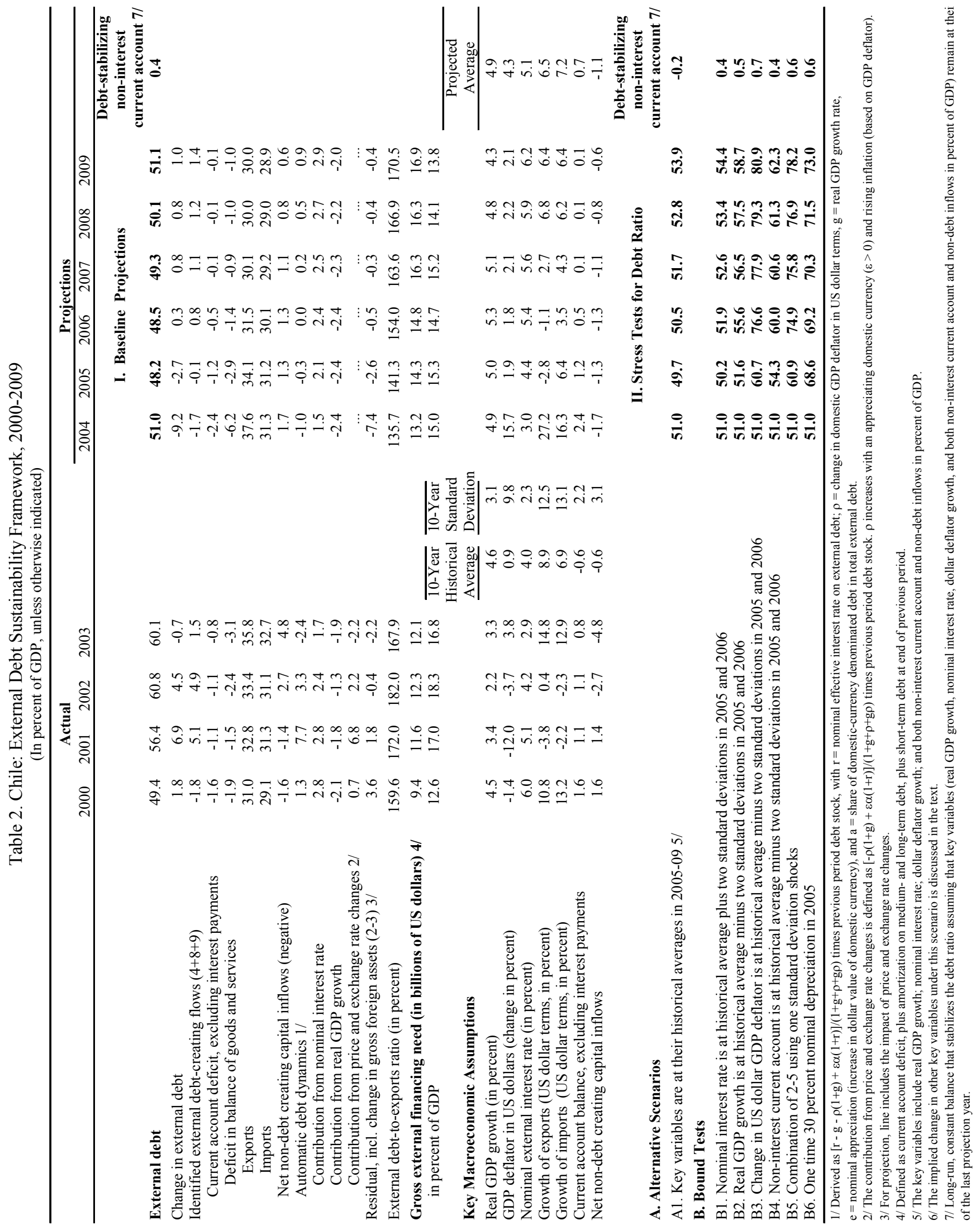




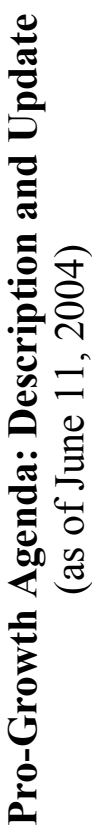

\begin{tabular}{|c|c|c|c|c|c|c|c|c|}
\hline & 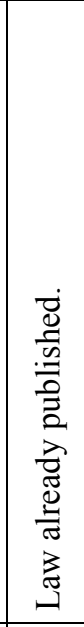 & 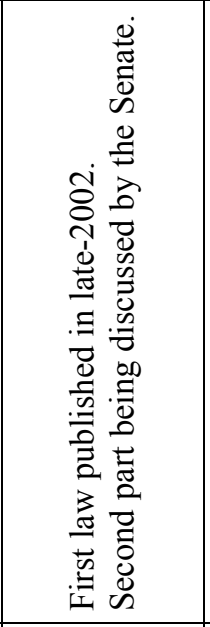 & 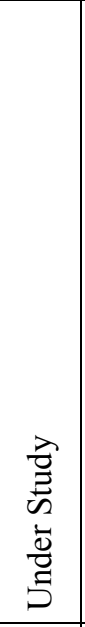 & 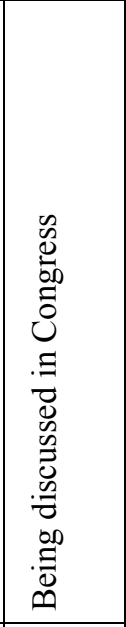 & 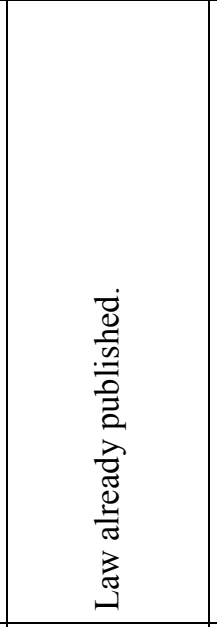 & 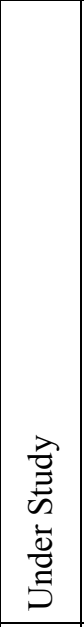 & 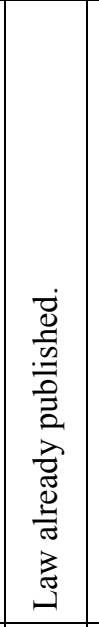 & 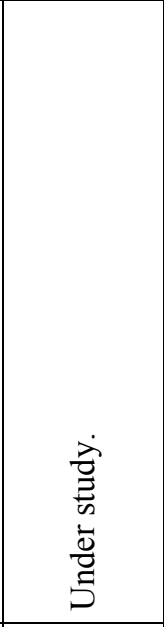 \\
\hline & 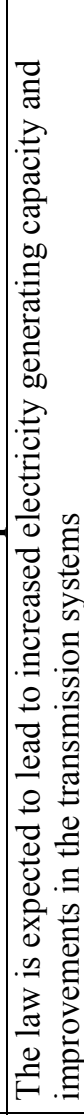 & 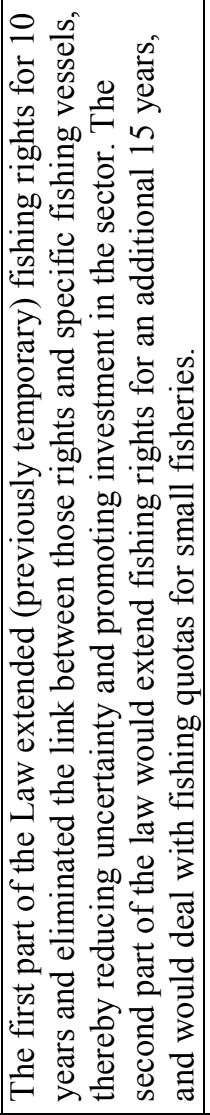 & 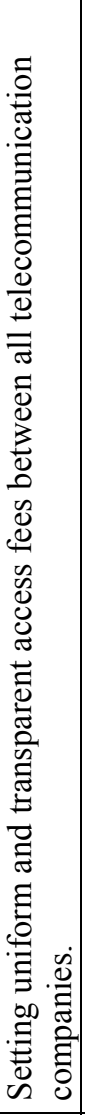 & 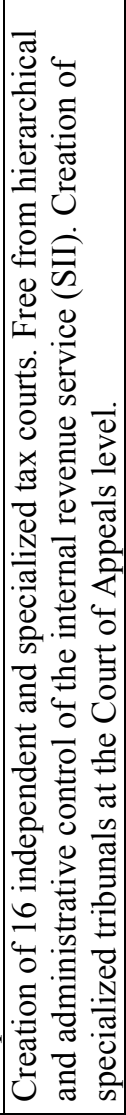 & 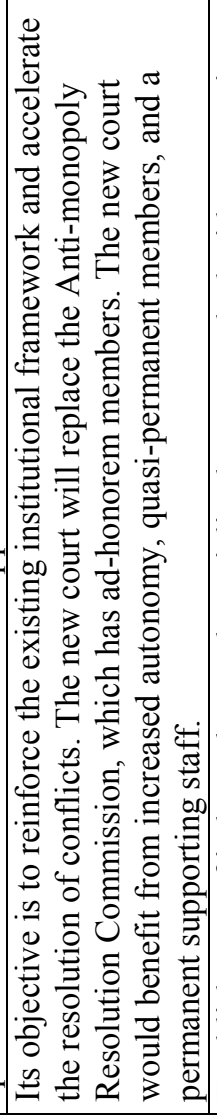 & 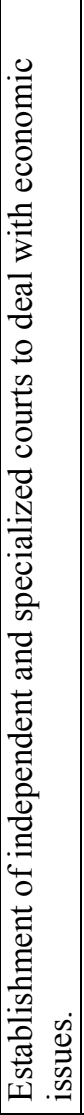 & 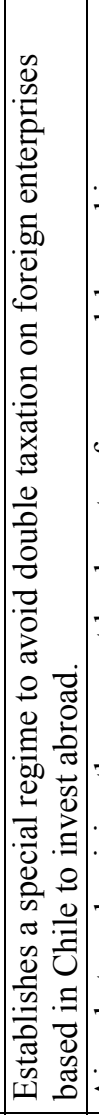 & 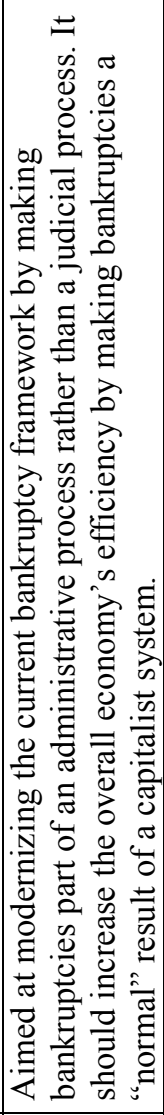 \\
\hline 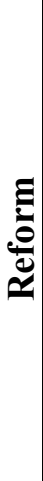 & 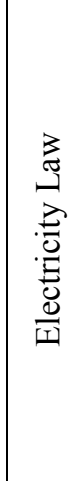 & 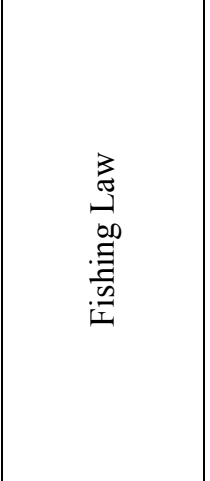 & 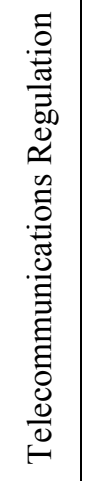 & 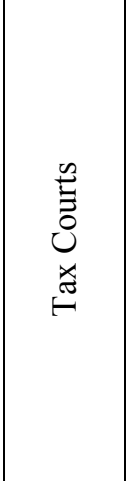 & 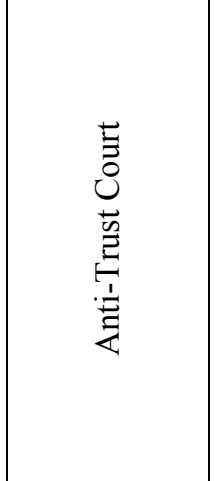 & 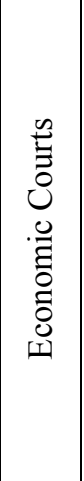 & 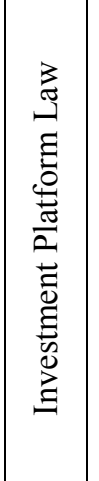 & 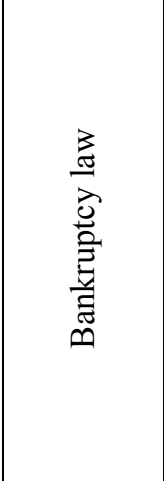 \\
\hline
\end{tabular}



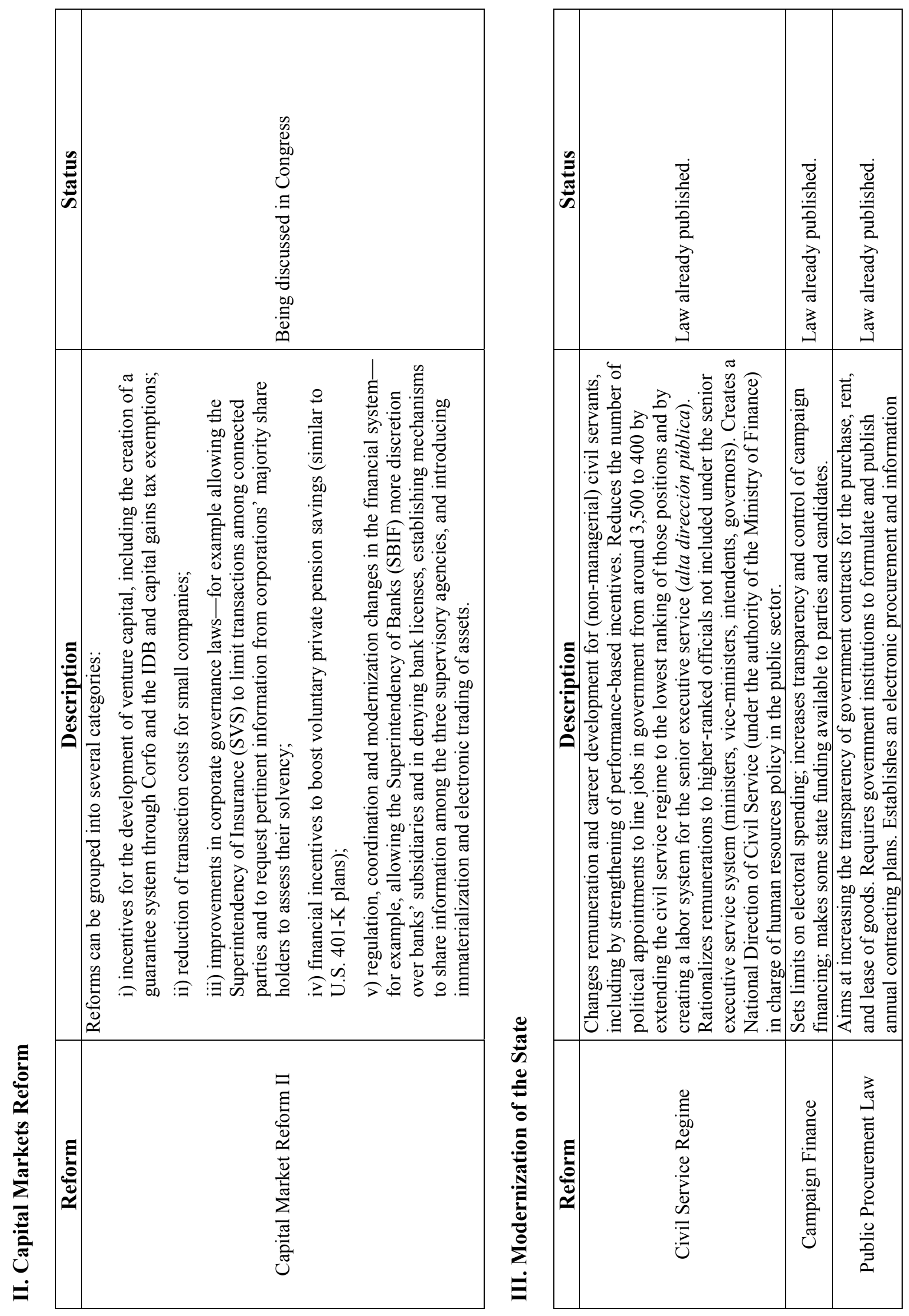

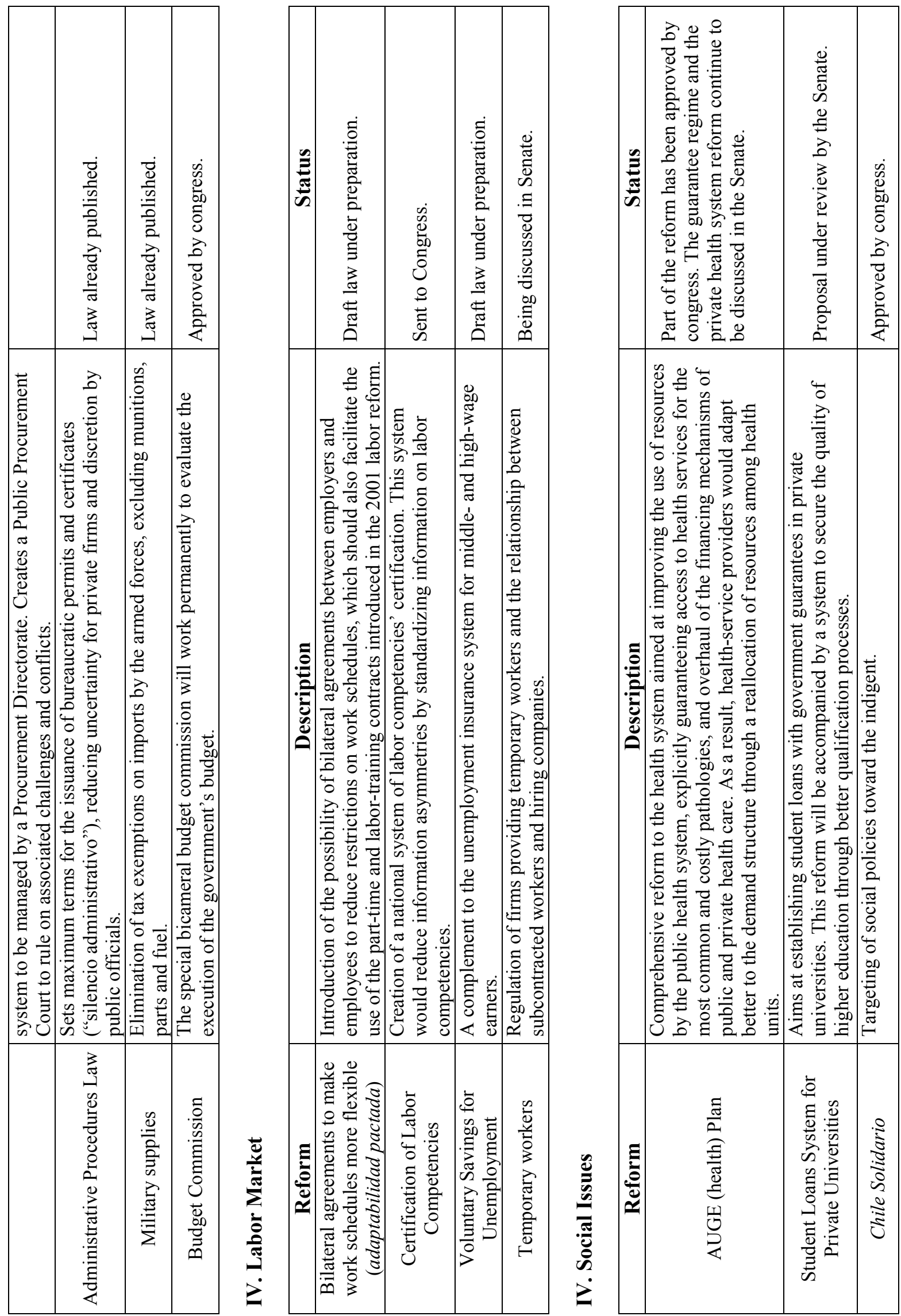


\section{INTERNATIONAL MONETARY FUND}

EXTERNAL

\section{IMF Concludes 2004 Article IV Consultation with Chile}

On August 4, 2004, the Executive Board of the International Monetary Fund (IMF) concluded the Article IV consultation with Chile. ${ }^{1}$

\section{Background}

Over the past two decades, Chile has adhered to a sound and consistent policy framework. Its policy mix has been based on open trade and exchange rate flexibility and, in recent years, inflation targeting and achievement of a fiscal structural balance rule-requiring a cyclicallyadjusted, central government fiscal surplus of 1 percent of GDP. During 2000-03, the actual overall balance of the central government registered a deficit of just below 1 percent of GDP and, in 2004, the accounts of the central government are expected to register a surplus of 1.5 percent of GDP.

Real GDP growth averaged 31/2 percent a year during 2000-03. Since the beginning of 2004, economic activity has picked up, in the context of a favorable external environment. The global economic recovery has helped boost export demand, particularly copper, the price of which has nearly doubled since end-2002. Chile has also benefited from low world interest rates.

Reflecting in part these developments, real GDP grew by $61 / 2$ percent in seasonally-adjusted terms during the first quarter, the strongest quarterly growth in 3 years, and the World Economic Outlook projects a rate of growth of 5 percent for the year as a whole. Despite steady, albeit modest, job gains, the unemployment rate has remained relatively high, at about $81 / 2$ percent.

\footnotetext{
${ }^{1}$ Under Article IV of the IMF's Articles of Agreement, the IMF holds bilateral discussions with members, usually every year. A staff team visits the country, collects economic and financial information, and discusses with officials the country's economic developments and policies. On return to headquarters, the staff prepares a report, which forms the basis for discussion by the Executive Board. At the conclusion of the discussion, the Managing Director, as Chairman of the Board, summarizes the views of Executive Directors, and this summary is transmitted to the country's authorities.
} 
The improvement in terms of trade registered in late 2003 and early 2004 contributed to an appreciation of the peso which, in turn, led to downward pressure on domestic prices. As a result, twelve-month inflation temporarily fell below the 2-4 percent inflation target range. In response to downward pressure on prices, and to provide stimulus to the economy, the central bank cut its policy interest rates twice, by 50 basis points on each occasion, in December 2003 and January 2004.

External conditions remain favorable. However, Argentina's decision to sharply cut natural gas exports is forcing domestic electricity generation to switch from relatively cheap natural gas to more costly diesel-generated power. At the same time, increases in petroleum import prices have raised costs further and dampened disposable income growth.

In the period ahead, the economy is expected to continue to gather momentum, and GDP is projected to grow by about 5 percent a year in 2004 and 2005. Reflecting a supportive external environment, high copper prices, and low interest rates, investment is expected to rebound in the second half of 2004. As a result of moderate above-trend growth, the output gap would close slowly, and inflation is expected to gradually return within the central bank's target band. High copper prices would help the external current account to register a surplus of about 1 percent of GDP in 2004.

\section{Executive Board Assessment}

Executive Directors commended the Chilean authorities for their continued implementation of sound policies, centered on a prudent fiscal policy, a successful inflation targeting framework, and trade integration. These policies, together with a robust financial system, have led to sustained economic growth and contributed to a sharp reduction in poverty, and constitute a good example for other countries. Directors also noted that strong fundamentals allowed Chile to weather the recent global downturn and should enable it to take full advantage of the rebound in copper prices and increased global demand for its exports, contributing to a long-delayed rebound in investment. Directors pointed to manageable risks associated with higher global interest rates, oil prices, uncertainties regarding natural gas supplies, and possible changes in copper prices.

Directors praised Chile's commitment to a prudent fiscal policy, reinforced by adherence to a structural balance rule, which calls for a surplus of 1 percent of GDP in the central government's fiscal accounts. They commended the authorities for reallocating spending to social priorities, and for restraining overall spending, despite higher revenues from the surge in copper prices. They supported the decision to use surpluses accrued in the Copper Stabilization Fund to selectively prepay government debt. Directors commended the authorities for improving transparency in the fiscal accounts and for publishing previously off-budget accounts, especially with regard to military spending. Going forward, they welcomed the inclusion of an estimate of the structural fiscal position in the budget. In this regard, several Directors recommended that the authorities formalize the structural balance rule into a law, while several other Directors thought that formalizing this rule would unnecessarily constrain the scope of countercyclical fiscal policy. 
Directors noted that the authorities' proposal to introduce a royalty in the mining sector could raise revenue and aid Chile's management of its non-renewable resources, though they cautioned that if introduced, it should be done in a manner that does not negatively impact foreign investment.

With regard to monetary policy, Directors recognized the success of Chile's inflation targeting framework in anchoring inflation expectations. They viewed the current stance of monetary policy as appropriate and as having provided adequate stimulus to the economy. Looking forward, with inflation gradually returning to the mid-point of the central bank's inflation target band of 2-4 percent, they advised only a gradual removal of monetary stimulus, given the large output gap and the persistence of a still high unemployment rate.

Directors agreed with the thrust of the central bank's debt management strategy.

They supported the central bank's ongoing process to deepen domestic financial markets by introducing long-term peso-denominated bonds. They agreed with the central bank's plans to gradually redeem part of its dollar-indexed debt with foreign exchange reserves. Directors encouraged the authorities to recapitalize the bank, which would contribute to resolving the bank's on-going quasi-fiscal deficits. A few Directors pointed to the need to link more explicitly the structural balance rule to the quasi-fiscal deficit of the central bank.

Directors observed that the floating exchange rate regime has benefited the economy and allowed it to adjust smoothly to external shocks. They commended the central bank for a policy of nonintervention in the foreign exchange market, despite the sharp appreciation of the peso in late 2003.

Directors welcomed the authorities' intention to follow the recommendations of the Financial System Stability Assessment. They agreed that the financial system is sound and has withstood well a large range of shocks over the past several years, and emphasized the important role of sound regulations and strong supervision, particularly in the banking system. They noted, however, the need to reduce risks in the insurance industry and strengthen regulation and supervision of the securities industry. They also saw a need to improve further Anti-Money Laundering/Combating the Financing of Terrorism legislation.

Directors agreed that there was scope for improving the financial system's efficiency. They suggested that investment restrictions on pension funds could be judiciously liberalized, to take advantage of economies of scale and increased competition. Directors highlighted the need for the regulatory system to adapt to the increasing sophistication of financial markets, where distinctions between entities had become more blurred, by moving to a high-quality risk-based regulatory system that would take into account the interconnections between different components of the financial system. They also noted that there was room to further improve competition regarding the financing of small and medium-sized enterprises. To that end, Directors welcomed the reforms contained in the new Capital Markets II draft law.

Looking to the medium-term, Directors praised the authorities' on-going public debate on how to sustain higher rates of growth while reducing income inequality. To that end, Directors supported the recent laws to implement the Pro-Growth Agenda. In this context, they noted the importance of liberalizing labor market laws and strengthening the educational system to 
improve employment opportunities. Directors also praised the authorities for their social policies, including Chile Solidario, which they viewed as an important example of a well-targeted program to help reduce extreme poverty.

Directors underscored Chile's leadership role in opening markets through comprehensive and sustained trade and financial market liberalization. They welcomed the implementation of recent bilateral trade agreements and also encouraged the authorities to continue their efforts at multilateral trade liberalization. They observed that Chile's exposure to external debt shocks remained contained, since much of this debt resides with the private sector, which has access to financial hedges, and external public debt ratios remain low.

Directors recognized that the data received by the Fund are of good quality, timely, and adequate for surveillance purposes. They commended the authorities for making important strides in bringing the fiscal statistics more closely in line with international standards and urged that the authorities take the steps needed to close the relatively small gaps in coverage. They also welcomed Chile's decision to participate in the pilot project to evaluate public investment and Public-Private Partnerships.

It is expected that the next Article IV consultation with Chile will be held on the standard 12month cycle.

Public Information Notices (PINs) form part of the IMF's efforts to promote transparency of the IMF's views and analysis of economic developments and policies. With the consent of the country (or countries) concerned, PINs are issued after Executive Board discussions of Article IV consultations with member countries, of its surveillance of developments at the regional level, of post-program monitoring, and of ex post assessments of member countries with longer-term program engagements. PINs are also issued after Executive Board discussions of general policy matters, unless otherwise decided by the Executive Board in a particular case. 
Chile: Selected Economic Indicators

\begin{tabular}{|c|c|c|c|c|c|c|}
\hline & 1998 & 1999 & 2000 & 2001 & 2002 & 2003 \\
\hline \multicolumn{7}{|c|}{ (Annual percentage change) } \\
\hline \multicolumn{7}{|l|}{ Production, prices, and trade } \\
\hline Real GDP & 3.2 & -0.8 & 4.5 & 3.4 & 2.2 & 3.3 \\
\hline Total domestic demand & 3.9 & -5.8 & 5.9 & 2.2 & 2.5 & 3.5 \\
\hline Consumption & 4.3 & -0.4 & 3.6 & 2.8 & 2.1 & 3.5 \\
\hline Investment & 2.2 & -20.1 & 14.0 & 0.5 & 3.9 & 3.5 \\
\hline Fixed & 1.9 & -18.2 & 8.9 & 3.6 & 1.4 & 4.8 \\
\hline Inventories $1 /$ & 0.1 & -0.6 & 0.5 & -0.6 & 0.5 & -0.2 \\
\hline Net exports 1/ & -0.8 & 4.8 & -1.4 & 1.3 & -0.2 & -0.1 \\
\hline \multicolumn{7}{|l|}{ Consumer prices } \\
\hline End of period & 4.4 & 2.5 & 4.6 & 3.0 & 2.9 & 1.1 \\
\hline Average & 5.1 & 3.3 & 3.8 & 3.6 & 2.5 & 2.8 \\
\hline Real wages & 2.7 & 2.4 & 1.4 & 1.6 & 2.0 & 0.9 \\
\hline Unemployment rate (annual average) & 6.2 & 9.7 & 9.2 & 9.2 & 8.9 & 8.5 \\
\hline Exports (U.S. dollars) & -8.7 & 5.1 & 11.9 & -4.9 & -0.5 & 15.8 \\
\hline Imports (U.S. dollars) & -4.8 & -19.8 & 16.0 & -3.9 & -3.1 & 13.3 \\
\hline Terms of trade & -5.0 & 5.7 & 5.1 & -7.4 & 4.0 & 4.8 \\
\hline Real effective exchange rate $2 /$ & -2.7 & -9.6 & -2.9 & -8.2 & -2.5 & 4.6 \\
\hline \multicolumn{7}{|l|}{ Money, credit, and interest rates } \\
\hline Broad money & 8.0 & 4.0 & 5.3 & 4.9 & 3.3 & 2.3 \\
\hline Credit to the private sector (end of period) & 3.9 & 7.2 & 12.1 & 8.1 & 9.6 & 11.4 \\
\hline Three-month interest rate $3 /$ & 16.4 & 10.7 & 10.8 & 7.2 & 3.9 & 4.8 \\
\hline \multicolumn{7}{|c|}{ (In percent of GDP) } \\
\hline \multicolumn{7}{|l|}{ Savings and investment } \\
\hline Gross domestic investment & 26.9 & 20.9 & 21.9 & 22.0 & 22.0 & 21.8 \\
\hline Public & 3.6 & 3.5 & 3.0 & 3.0 & 2.8 & 2.5 \\
\hline Private & 23.3 & 17.4 & 18.9 & 19.0 & 19.1 & 19.3 \\
\hline National savings & 22.0 & 21.0 & 20.7 & 20.4 & 20.7 & 20.9 \\
\hline Public 4/ & 2.9 & 1.1 & 1.8 & 2.4 & 1.8 & 2.9 \\
\hline Private & 19.1 & 20.0 & 18.9 & 18.0 & 18.9 & 18.0 \\
\hline External savings & 4.9 & -0.1 & 1.2 & 1.6 & 1.3 & 0.8 \\
\hline \multicolumn{7}{|l|}{ Public sector finance } \\
\hline Central government balance & 0.2 & -2.4 & -0.9 & -0.9 & -1.4 & -0.5 \\
\hline Central government gross debt & 12.5 & 13.7 & 13.7 & 15.0 & 15.7 & 13.3 \\
\hline \multicolumn{7}{|l|}{ Balance of payments } \\
\hline Current account & -4.9 & 0.1 & -1.2 & -1.6 & -1.3 & -0.8 \\
\hline Financial account 5/ & 2.2 & -1.1 & 1.6 & 0.7 & 1.6 & 0.3 \\
\hline \multicolumn{7}{|l|}{ External Debt } \\
\hline Gross external debt & 41.1 & 47.6 & 49.4 & 56.4 & 60.8 & 60.1 \\
\hline Public & 7.3 & 8.2 & 8.0 & 9.0 & 11.1 & 12.9 \\
\hline Private & 33.8 & 39.4 & 41.4 & 47.4 & 49.7 & 47.3 \\
\hline
\end{tabular}

Sources: Central Bank of Chile, Ministry of Finance, Haver Analytics, and IMF staff estimates.

1/ Contribution to growth.

2/ End of period; authorities' definition of the real effective exchange rate. A decline indicates a depreciation of the peso.

$3 /$ Nominal rates, in percent per annum, period average, on 90-day central bank promissory notes.

4/ Gross saving of the general government sector, including the deficit of the central bank.

$5 /$ Including errors and omissions, but excluding reserves. 


\section{Statement by Guillermo Le Fort, Executive Director for Chile August 4, 2004}

\section{Key points}

- Growth has accelerated, following the thrust of exports, private consumption, and more recently investment, in a relatively balanced way across sectors.

- Higher prices for copper as well as for other exports have markedly improved the terms of trade; the open trade strategy has permitted a sustained diversification of Chile's export base, as shown by the rapid increase in non-copper exports.

- Employment growth remains sluggish, productivity is growing fast and the unemployment rate is declining slowly. The recent acceleration in investment growth should contribute towards a faster reduction in unemployment.

- The flexible exchange rate and the credible-rules-based monetary and fiscal policies allow demand-management policies to act counter cyclically.

- Risks to the growth outlook appear manageable including that of the energy sector, where diversification of supply continues.

- The level of the private sector's gross external debt does not represent a source of vulnerability.

- The FSAP indicates that the financial system is well-developed, sound, and resilient to shocks, and helps to identify possible reforms and improvements, some of which are already underway.

- Under the currently supportive external environment, and the strength of its policy framework and institutional arrangements, Chile is well positioned to return to faster medium-term growth rates.

- Improving the efficiency of the education system and well-focalized social policies continue to be priorities for the Chilean government.

1. The Chilean authorities once again express their appreciation to the staff for the valuable policy discussions, including the FSAP exercise, as well as for the set of useful reports produced for this consultation. My authorities consent to the publication of the Staff Report, the FSSA, and the Special Issues Papers. Chile's home-grown economic strategy has been strengthened by a close policy dialogue with the Fund, despite having sometimes different views on specific issues. The consultation process has contributed to refine some policies, but more importantly has helped to better convey to the international community and financial markets the foundations of Chile's strategy.

2. Concerns about the re-acceleration of economic activity that were important in last year's consultation have now largely subsided, with a balanced growth process taking hold. GDP growth in the second quarter will be about 5 percent, while the consensus growth forecast for this year has been raised to a similar rate, up from 4.5 percent at the time of last's year consultation. The significant strengthening of external demand and the improvement of the terms of trade have led to an unprecedented export expansion during the first half of this 
year (39 percent in value terms, compared to the first half of last year's). The dynamism of exports, coupled with a supportive monetary policy, has also been transmitted into faster domestic demand growth, a phenomenon that was first evident in private consumption, and that more recently is also seen in private investment, particularly in machinery and equipment. Sectoral growth has been relatively balanced with Manufacturing, Agriculture, Construction, Commerce, and Transport and Communications growing between 4.5 and 6.5 percent during the first quarter this year. The exceptions in sectoral growth are the fisheries that have expanded at two-digit rates, as a result of the sustained growth in fish farming and the recovery of the traditional fishing activity after a particularly bad year and Mining that suffered a temporary delay in the expansion of new projects.

3. Copper continues to be very important for the Chilean economy, and this year's extraordinarily high prices have certainly been a key factor favoring the ongoing recovery. Nevertheless, prices of other exports are also contributing to the improvement in the terms of trade. In fact, the open-trade strategy has permitted a sustained diversification of Chile's export base, with copper falling to 36 percent of total exports of goods. In particular, this year non-copper exports are growing close to 15 percent in volume terms. Such a diversification process, together with a consistent macroeconomic policy framework and effective financial sector regulation and supervision, has helped to increase the Chilean economy's resilience to external shocks. Moreover, as recognized by the staff in the context of last year's Article IV Consultation, the natural resource content of the Chilean export basket does not represent a barrier to long-term growth.

4. Notwithstanding the acceleration of output growth and the generalized sectoral expansion, employment growth has remained somewhat sluggish. On the positive side, this implies that a very significant expansion in productivity is taking place; however, it also suggests that the sharp reduction in the unemployment rate that would strengthen the recovery in private consumption has not developed yet. The unemployment rate peaked at 11.5 percent in mid 1999 after a short-lived recession, and since then has gradually come down reaching just over 9 percent in mid 2004, reflecting years of slow growth in output and employment. Currently, however, with output growth robustly picking up, the unemployment rate should decline more markedly. Such expectations have not being fulfilled so far, probably due to the movements within employment towards better and more formal jobs, and the return to the labor force of previously discouraged workers, as the perceived probability to find employment increases in upturns. Eventually, however, the recent recovery in investment expansion should translate into more dynamic employment creation and lower unemployment rate.

5. The credibility of the independent Central Bank of Chile $(\mathrm{BCCH})$ has allowed the implementation of a countercyclical monetary policy that is significantly contributing to the ongoing recovery of domestic demand. Inflation, which has in general remained within the target band, currently is converging towards it from below, after suffering the effects of supply shocks that led to a short period of negative inflation some months ago. The consolidation of low inflation is also facilitating the development of the capital market. In such direction, the recently introduced 10-year Central Bank bonds denominated in Chilean pesos are the longest non-indexed domestic currency instrument ever issued by the Chilean 
public sector. Their yield (6.5\%), and that of indexed instruments of the same maturity $(3.7 \%)$, means that the sum of implicit inflationary expectations and a risk premium or discount are slightly below 3 percent. The alignment of inflationary expectations with the center of the inflation target range, also confirmed by surveys, speaks by itself about the credibility that monetary policy commands.

6. The significant monetary stimulus would not have been possible without the room of maneuver provided by the floating exchange rate system, the rules-based fiscal policy, and the overall credibility of the policy framework. Foreign currency intervention has not been used since early 2003, and a mix of financial regulations and market development has prepared the private sector to confront exchange rate fluctuations. Fiscal policy has effectively targeted a structural surplus equivalent to 1 percent of GDP for the central government balance also during the upswing, and a nominal fiscal surplus above 1 percent of GDP is expected for this year. The fiscal authorities have gathered wide support for their self-imposed rule by successfully explaining to the public the concepts and purpose of the structural target for fiscal policy. The structural fiscal target is aimed at allowing the automatic stabilizers to operate throughout the cycle, so as to avoid a pro-cyclical bias that characterized fiscal policy in the past, and that is a common feature among emerging market economies. Both, fiscal and monetary policies display high and increasing levels of transparency, as recognized in last year's Fiscal ROSC, and this year Monetary ROSC.

7. As mentioned by the staff, my authorities feel confident that risks to the short and medium term outlook appear manageable. In particular, the effects of the disruption of natural gas supplies from Argentina have been contained, and recent news in this respect have been favorable, thus reducing the moderate impact on output growth and energy costs mentioned in the report. It is worth noting that the more intensive use of natural gas of recent years added an element of diversification to Chile's energy matrix, historically concentrated in hydroelectric power. The unreliability of the new supply source and the demand pressures resulting from faster actual and projected economic growth, are prompting the industry to search for alternative energy sources, including importing natural gas from outside the region, geo-thermal energy, and bringing forward the coming on stream of future hydroelectric projects.

8. Concerns related to the "relatively high" Chilean corporate external debt are founded in a very partial view of the private sector's financial position. First, as acknowledged by the staff, a substantial part of that debt corresponds to companies owned by non-financial multinationals, of which a significant part is due to their parent's company. Second, Chile's indicators of gross private external debt are below those of advanced economies. Third, the large accumulation of assets held abroad by Chilean corporations and institutional investors cannot be ignored when analyzing the private sector's solvency. If the intention is to study financial risks, just focusing on gross debt does not provide an overall picture, and therefore should be complemented with a more comprehensive analysis of the asset-liability mismatches of private corporations. In this regard, the development of derivatives markets for exchange-rate risk is reassuring in the sense that corporations have access to hedging instruments, while regulations on financial intermediaries and the incentives structure of a floating exchange rate system promotes a more wide-spread use of hedging strategies. 
Moreover, liquid external assets of the private sector cover a significant portion of their shortterm external liabilities. Finally, international capital markets have continuously improved their risk evaluation of Chilean corporations, and bond spreads for a representative sample of them have continued to narrow - from an average of 280 basis points last year, to around 200 basis points on average throughout this year.

9. The FSAP exercise has been extremely useful. The core message of the FSSA is that the Chilean financial system is relatively large, sound, well diversified, and resilient to shocks. The strengths of the banking system and of the supervisory and regulatory institutions were particularly underscored. The important role played by pension funds and their substantial accumulation of domestic and external financial assets over the years - which has been instrumental for the development of the whole financial sector-was also recognized.

10. Notwithstanding the relatively smooth performance of the financial sector during the difficult times of the late 1990 s and early 2000 s, several areas that require strengthening in order to further improve the efficiency of resource allocation are adequately identified in the FSSA. The recommendations have been welcomed and work in this regards has been started. The Central Bank and the SBIF have published a proposal for reforming regulations on market risk at banks along the lines of the 1996 amendment on the Basle capital accord, and they are considering the scope of derivative intermediation open to banks. Also, the Central Bank has recently revamped the payment systems and work continues to improve the infrastructure for clearance and settlement of securities. Also, the Capital Markets II initiative - which addresses some of the FSAP recommendations - and another bill that introduces additional flexibility to the ceilings on lending interest rates by making them more productspecific, have recently been submitted to Congress. Other initiatives that require a more careful consideration of the legislative work needed for their development and/or more sophisticated and time consuming technical treatment will follow. Finally, the BCCH will soon start periodically publishing a Financial Stability Report, so as to enhance surveillance of the domestic financial market and its interrelations with the international capital markets.

11. The outstanding performance of the economy during the nineties can be explained in terms of a sustained process of reforms, institution building, and strengthening of the macroeconomic policy framework. The contagion from crisis episodes in emerging markets and the weak global conditions of the turn of the century slowed down the rate of growth during the last five years. Under the currently supportive external environment, and the strength of its policy framework and institutional arrangements, Chile is well positioned to return to a higher growth path. However, the extent of the acceleration going forward is a matter of debate. The committee of independent experts that generate the parameters used in the calculating the fiscal structural balance has estimated 4.1 percent as the growth rate of potential output. Including the absorption of the existing output gap, average growth over the next 4 years is projected at 5.2 percent. Yet, taking into account recent advances - such as the free trade agreements signed with major trade partners, structural reforms (capital markets, civil service, education, health, sanitation, etc.) and the massive effort in infrastructure building as well as the prospects for a more robust return of capital inflows and foreign investment which have remained depressed over the last few years - there is room for greater optimism about the long-term prospects for the Chilean economy. 
12. Improving the efficiency of the education system is a necessary condition to sustain higher economic growth. It should be noted however that many of the observed weaknesses in the quality of education can be attributed to the rapid expansion of the system's coverage. In addition, several projects aimed at increasing the quality of education are already underway. In a similar vein, well-focalized social policies continue to be a priority for the Chilean government, and despite the impressive advancement in poverty reduction over the last decade, the authorities are aware of the significant pockets of poverty that still remain. Consequently, my authorities have very ambitious tasks in terms of reducing extreme poverty and have developed a special and well-focalized program, Chile-Solidario, to increase the access to social services by marginalized segments of the population, mostly in rural areas. A more balanced wealth and income distribution is likely to be an outcome of the sustained implementation of policies aimed at ensuring equal opportunities. 